\title{
Şer'iyye Sicillerine Göre XIX. Yüzyılın İlk Yarısındaki Osmanlı-Rusya İlişkilerinin Kıbrıs'a Yansıması: Konsoloslar, Tüccarlar ve Ticaret
}

\author{
The Impact of The Relations Between The Ottoman Empire and Russia on \\ Cyprus in The First Half of The 19th Century According to The Sharia Court \\ Records: Ambassadors, Merchants and Trade
}

\section{Celâl ERDÖNMEZ*}

Mehmet Akif Ersoy Üniversitesi Eğitim Fakültesi, Burdur-Türkiye, celalerdonmez@mehmetakif.edu.tr

ORCID Numarası | ORCID Number: 0000-0002-3173-1936

\begin{abstract}
ÖZ
Bu çalışmada, Osmanlı Devleti ile Rusya'nın XIX. yüzyılın ilk yarısındaki uluslararası ilişkileri ticaret ve konsolosluk kurumu etrafında incelendi. Çalışmanın amacı iki devlet arasındaki kırılgan siyasî, askerî ve diplomatik ilişkilerin bir Doğu Akdeniz adası olan Kıbrıs üzerindeki ticarî tesirlerini tespit etmektir. Bunun için konsolosluk faaliyetleri ve ticarî ilişkilerin incelenmesi tercihen seçildi. Konu, Osmanlı Arşivi vesikaları ile Kıbrıs arşivlerindeki Şer'iyye Sicilleri'nde yer alan belgelere istinaden incelendi. Çalışmanın sonunda; Rusya tüccarlarının Kıbrıs'ta iki devlet arasındaki anlaşmalar çerçevesinde ticaret yaptıkları, yüzyılın başındaki savaşların Osmanlı Devleti tarafından üretilen resmî evrakın yazım üslubuna olumsuz ifadelerle yansıdığı ve sıcak savaş dönemlerinde Kıbrıs'ta fiyat dalgalanmaları olduğu görüldü. 1821 yılında başlayan Mora isyanında Rusya Konsolosluğu'nun Rumlara destek vermesi sebebiyle ilişkiler dondurulmuştur. Barış dönemlerinde ise Rusya tüccarları ve konsolosları Kıbrıs'ın taşra köylerindeki yerli halk ile de temasta bulunmuştur. Tanzimat devri başlarından itibaren konsolosların adadaki muhassıllarla işbirliği yaptıkları, bu vesileyle iltizam işlerinin işleyișine müdahale imkânı kazandıkları ve mültezimler aleyhinde ada yöneticileri üzerinde baskı kurdukları görülmektedir. Osmanlı Devleti'nin İngiltere’ye 1838 yılında Balta Limanı Ticaret Antlaşması'yla verdiği hakların İngiltere tüccarlarına sağladı̆̆ı tekel statüsünü kırmak amacıyla, Rusya tüccarlarına vergi ödemeksizin Osmanlı ülkesinden ihracat yapma imkânı sağlanmıştır. Bu dönemin en belirgin dış politika eylemi olan büyük devletlerin arasında denge kurma siyaseti, genelde Osmanlı ülkesi, özelde Kıbrıs adasında Rusya'ya ihracat gümrügü rejiminde avantajlar sağlanması suretiyle ticari olarak da uygulanmıştır.
\end{abstract}

Anahtar Kelimeler: Rusya, Osmanlı Devleti, Kıbris, Konsolos, Ticaret

\begin{abstract}
Within this study, international relations between the Ottoman Empire and Russia in the first half of the 19th century were examined with regard to international trade and institution of consulship. The aim of the study is to confirm the commercial influences of the fragile politic, military and diplomatic relations between these two states on Cyprus, which is an Eastern Mediterranean island. In accordance with this purpose, the activities of the Russian Consulate and trade relations were chosen to be examined. The subject was scrutinized considering both the Ottoman archives and the Sharia Court records located in the archives of Cyprus. It was found that the Russian merchants were trading based on the commercial agreement between Russia and the Ottoman Empire, and that the wars at the beginning of the century negatively affected the turn of phrase of the Ottomans on keeping the registers, in addition to that, fluctuations in prices were seen in Cyprus during the hot war period. Within the period of the revolt in Morea which started in 1821, relations with Russia were suspended by the Ottoman Empire because the Russian Ambassador of that time stood by the side of the Greeks of Morea. During peacetime, Russian merchants and ambassadors kept in touch with the indigenous peoples of the countryside in Cyprus as well. It can be seen that, dating from the beginning of the Tanzimat Era, the ambassadors collaborated with the tax collectors and hereby they found a chance to intervene in the process of entitling exclusive authority on government property, and thus they exercised control over the rulers of the island against the contractors of that time. With the aim of the abolition of privileges and the monopoly status of British merchants, which were granted under the Treaty of Balta Liman signed in 1838, the right of exporting taxlessly from the Ottoman lands was provided to Russian merchants. The most important foreign policy act of this period i.e. protecting the balance between the major countries was commercially implemented by providing Russia with some advantages on the export tariff in the Ottoman lands, especially in Cyprus.
\end{abstract}

Keywords: Russia, Ottoman Empire, Cyprus, Ambassador, Trade 


\section{Giriş}

XIX. yüzyı1 başlarında Kıbrıs, bir Osmanlı adası olarak uluslararası siyasî ve ticarî rekabetin merkezinde yer alıyordu. Kıbrıs; İngiltere, Fransa ve Rusya gibi büyük devletlerin yanında Avrupalı tüm devletlerin de diplomatik ve ticari ilişkiler içinde olduğu bir yerdi. Ada, Doğu Akdeniz'de önemli bir mevkide bulunuyordu. Bu haliyle Kıbrıs, yıkılma sürecini durdurmak üzere yapısal çareler arayan Osmanlı Devleti ile İmparatorluk olarak genişlemek için Akdeniz'e inmeyi stratejik hedef addeden Rusya arasındaki mücadelelere de sahne oluyordu. Bu çerçevede Osmanlı Devleti ile Rusya arasındaki ezeli rekabetin etkileri Kıbrıs'a çok boyutlu olarak yansımıştı. İki devlet arasındaki ilişkilerin ada üzerindeki etkilerinin önemine rağmen Kıbrıs tarihçiliğinde üzerinde göreceli olarak en az eser verilen konu Kıbrıs'ta Rusya'nın varlığıdır. Rusya'nın Kıbrıs'taki diplomatik ve ticarî varlığı çoğunluğu Kıbrıslı tarihçilerce yapılan doktora çalışmalarında, genel kapsamlı olarak ele alınmıştır. Bu çalışmalarda Rusya'nın Kıbrıs'taki faaliyetleri çoğunlukla belirli bir döneme mahsus olmak üzere ve çoğu zaman konsolosluk faaliyetleri çerçevesinde değerlendirilmiştir (Çoruh, 2008, s. 334; Dinç, 2010, s. 329-332). Kaynak ve müracaat eseri mahiyetindeki çalışmalarda da bu konulara değinilmiştir (Cobham, 1908; Hill, 1952; Luke, 1969). Rusya'nın adadaki faaliyetleri, XVIII. yüzyıl sonları ile XIX. yüzyıl başları aralığında, konsolosluk kurumu etrafında müstakil bir çalışmayla incelenmiştir. İngilizce olarak neşredilen bu çalışma, bu konuda Türkiye'de yapılan ilk çalışmadır (Demiryürek, 2015, s. 715726). Osmanlı-Rus ilişkilerinin Kıbrıs'a yansıması, XVIII. yüzyılın son çeyreği ve savaş yılları esas alınarak yine İngilizce olarak neşredildi (Dinç, 2018, s. 63-76).

Öte yandan Osmanlı- Rusya ilişkileri, bir bakıma Rusya'nın Osmanlı topraklarına ilgisi çeşitli çalışmalarda ele alınmış olmasına rağmen ((Saul, 1970; Kurat, 1990; Çapraz, 2012), XIX. yüzyıl başlarında Osmanlı Devleti ve Rusya ilişkilerinin Rusya'nın Kıbrıs'taki ticarî ve konsolosluk faaliyetleri ve ada ticareti ile toplumu üzerindeki tesirleri hakkında çalışma yapılmamıştır. Buna paralel olarak bu iki büyük güç arasındaki yayılma-savunma-rekabet temelli mücadelenin adaya yansımalarının neler olduğu tespit edilmemiş̧ir. Bu çalışmada, Kıbrıs'ta Rusya'nın ticarî ve diplomatik temsilcileri olan konsolosluk kurumu ile Rusya tüccarlarının Ada'daki faaliyetleri ve tüm bunların Osmanlı-Rus ilişkilerinden ne şekilde etkilendikleri ele alınmıştır. Bunun için Osmanlı Arşivi vesikaları ile Kıbrıs Milli Arşivi Şer'iyye Sicilleri'nden tespit edilen veriler kullanılmıştır. Kıbrıs Şer'iyye Sicilleri, standart muhtevalarına ilave olarak; İstanbul Hükümeti'nin Kıbrıs'ı da ilgilendiren hususlarda Rusya ile kurumsal ilişkileri çerçevesinde yaptığı yazışmaların Kıbrıs idarecileriyle de paylaşıldığı birer kaynak mahiyetindedir. Öte yandan sicillerdeki tereke kayıtları, devlet ve idareci sınıftan farklı olarak, doğrudan doğruya halktan bireylerin durumunu tespit imkânı da sunmaktadır. Bu durum ise meseleye toplumsal tasnifin en alt katmanlarından bakılmasına imkân sağlar niteliktedir.

\section{Osmanlı Devleti’nde Rusya Konsolosluklarının Açılması}

Rusya'nın dış politikasında tarihsel stratejisinin sıcak denizlere inmek olduğu bilinen bir gerçektir. Bu strateji asırlar içerisinde önce Karadeniz kıyılarında Osmanlı Devleti ile sınırdaş olup ardından Akdeniz'e ulaşılan süreçte gerçekleştirildi.

XV. yüzyıldan itibaren Osmanlı ülkesinde görülen Rus tüccarlara 1739 y1lında Belgrad Muahedesi ile Karadeniz hariç olmak üzere Osmanlı suları ve topraklarında ticaret yapma imtiyazı tanınmıştı (Kütükoğlu, 2018, s. 314). Azak Denizi ile Karadeniz'de savaş ve ticaret gemisi bulundurması yasaklanmıştı (Kurtaran, 2014, s. 224). Rusya, söz konusu ticari imtiyazlarını değerlendirerek, XVIII. yüzyılın ikinci yarısında sıcak denizlere inme hedefini gerçekleştirmek için önemli firsatlar yakalamaya başladı. Osmanlı Devleti ile imzaladığı 1774 tarihli Küçük Kaynarca Antlaşması, Rusya'nın, Osmanlı politikasını yeni bir sürece soktu. Osmanlı gayrimüslimleri üzerinde, özellikle Ortodoks Hıristiyanların koruyucusu sıfatı önemli idi. Rusya bu koruma hakkını yerinde icra 
edebilmek için Osmanlı topraklarında, yasal bir zeminde faaliyet gösterebilmeliydi. Ticaret ve ticari faaliyetler çerçevesinde konsolosluk kurumundan bu istikamette azami derecede faydaland ${ }^{1}$.

Rusya'nın Osmanlı ülkesindeki ticari faaliyetleri ve ticaret ağı yanında diplomatik ilişkilerin taşra ayağını temsilen konsolos tayini, 1774 Küçük Kaynarca Antlaşması'nın 11. maddesinde zikredilen "Osmanlı Devleti sınırları içerisinde istediği yerlere konsolos veya konsolos vekilleri tayin edebileceği" hükmüne dayanıyordu (Köse, 2006, s.189). Bunun ardından 21 Mart 1799 tarihinde imzalanan Aynalıkavak Tenkihnâmesi'nin 6. maddesi iki devlet arasındaki ticari düzenlemeleri ihtiva ediyordu (Köse, 2006, s. 177). Nitekim bu antlaşmalar yürürlüğe girer girmez Rusya; Balkanlar (Köse, 2006b, s. 141-155) yanında Akdeniz, Doğu Akdeniz liman şehirleri ve adalarında konsolosluklar açtı ${ }^{2}$. Bunlar içerisinde Kıbrıs da vardı ${ }^{3}$. Rusya'nın bu girişimleri, İngiltere'nin bölgede yürütmekte olduğu ticarî faaliyetlerine karşı yürütmekte olduğu etkili rekabetin de bir sonucu idi (Anderson, 1954, s. 40).

Rusya konsolosları, görünüşte görev yerlerinde Rus tüccarların işlerine yardımcı olmak üzere tayin edilmelerine rağmen, aslında devlet aleyhinde faaliyetler ve reayayı isyana sevk edecek girişimlerde bulunmakla görevlendiriliyorlardı. Rusya, diğer Avrupa devletleri gibi, Osmanlı Devleti tarafından tanınan müste'men statüsündeki tüccarları ile Osmanlı ticaretine dâhil olmuştu (Bağış, 1983). Kıbrıs'a da 27 Temmuz 1785 tarihi itibariyle müste'menlerden birini konsolos olarak görevlendirmişti (KŞS., 21/29-3) .

Kıbrıs Adası, daha bu dönemde büyük devletler tarafından ele geçirilmeye çalışılan bir yerdi. Rusya, Küçük Kaynarca Antlaşması ile Osmanlı Devletine teyit ettirdiği askeri ve diplomatik gücü ile Kıbrıs üzerinde de tasarrufta bulunmaya çalışıyordu. Kıbrıs Adası, Rusya ile dönemin etkili devletlerinden Avusturya arasında diplomatik pazarlık konusu ediliyordu. Bu çerçevede 1780'de iki devlet arasında yapılan gizli anlaşma ile Rusya, Mora yarımadası ve Girit yanında Kıbrıs'1 da Avusturya'ya bağışliyordu (Köse, 2006a, s. 316).

Rusya'nın Küçük Kaynarca Antlaşması'ndan sonra Osmanlı ülkesinde konsolosluklar açma girişimi Osmanlı idarecilerinin tepkileriyle karşılaştı. Osmanlı Devleti söz konusu antlaşma kendi temsilcilerinin elinden çıkıp onaylanmamışçasına inkârcı bir tutum içerisinde durumu değerlendiriyordu. Rusya, antlaşmada zikredilen "Âmme-i mevâki" ibaresine vurgu yapmakta ve bu girişimlerinin anlaşma çerçevesinde kendilerine tanınmış bir hak olduğunu savunmaktaydı.

Küçük Kaynarca Antlaşması üzerine yapılan müstakil bir çalışmada, Osmanlı Devleti idarecileri tarafından Küçük Kaynarca Antlaşması'nda Rusya'nın uygun göreceği yerlere konsolos atayabilmesini ifade eden "Âmme-i mevâki" ibaresinin her türlü yoruma açık olduğunun farkına varılmadığ 1 belirtilmektedir (Köse, 2006a, s. 190). Ancak böyle yorumlar yapılsa da Ruslar, bu ibareden hareketle çoğu zaman Osmanlı Devleti makamlarına rağmen muhtelif yerlerde konsolosluklar açmıştı ${ }^{5}$. Kıbrıs Şer'iyye Sicillerinde yer alan nüshası verilen tayin beratı da "Rusya Devleti tarafindan lâzım görülecek âmme-i mevâki 'de” ibaresini içermektedir (KŞS., 21/29-3). Bu tarz

\footnotetext{
1 Büyük devletler, Osmanlı gayrimüslim tebasının koruyuculuğunu bahane ederek devletin iç işlerine daha rahatlıkla karışacaklardı. Osmanlı Devletinin çeşitli yerlerinde, özellikle Kıbrıs’ta konsolosluklarını misyoner merkezi haline getirmişlerdi. (Çevikel, 2000, s. 112; Aksın, 2002, s. 1029, 1031).

2 Rusya'nın Osmanlı Devleti içinde stratejik mevkilerde yürüttüğü ticari faaliyetleri Rus kaynaklarından da değerlendirilmiştir. (Prousis, 2003, s.127-138).

${ }^{3}$ Rusya Selanik, İzmir, Rodos, Girid, Sakız, Sisam, Boğazhisarları, Trablusşam, Mora, İskenderiye, Sayda, Arnavutluk, Eğriboz Adası, Santeron, Nakşa, Eflâk ve Boğdan'a konsolosluklar açtı. ( Köse, 2006a, s. 189).

4 Rusya, Kaynarca Andlaşması'nın imzalanmasını müteakip bir anda her yere konsolos veya konsolos vekilleri gönderemediğinden, tespit ettiği bazı yerlere müste'men memurlar görevlendiriyordu. (Köse, 2006a, s. 189).

5 Eflak-Boğdan ve Silistre konsoloslukları Osmanlı idarecilerinin karşı çıkmasına rağmen açılmıştı. Mikenos Adası'na yapılacak konsolos tayinine karşı çıkılmasını Rusya savaş sebebi sayacak kadar ileri gitmişti. ( Köse, 2006a, s. 193 vd).
} 
ibarelerin yazımında Rusya lehine bir geleneğin oluştuğu anlaşılmakla birlikte başka bir örnekte de Osmanlı Devleti idarecilerinin kritik bir ibareyi “Yanlışlıkla” yazdıkları görülmektedir.

\section{Rusya'nın Kıbrıs'taki Konsolosluğu}

Rusya'nın Kıbrıs'taki konsolosluk faaliyetleri, başlangıcından 1800 yılına kadar, İngilizce olarak yayınlanmış bir bildiride kısaca değerlendirilmiştir (Demiryürek, 2015, s. 715-726). Buna göre Rusya 18. yüzyıl sonlarında Balkanlar ve Ege kıyı şehirleri yanında Akdeniz havzasında da önemli bir konsolosluk ağı kurmuştu. Bu meyanda Rusya'nın Kıbrıs'taki ticari ve konsolosluk faaliyetleri 18. yüzyıl sonlarından beri devam ediyordu ${ }^{6}$. Kaptan İvan Ecali 1785 yılı ortalarında, Rusya tarafindan Kıbrıs konsolosluğuna gönderilmişti (KŞS., 21/29-3). İlerleyen zamanlarda, 1799 yılında, bu göreve Mensel Veni Ran Mensel tayin edildi (Özkul, 2013, s. 268). Onun vefatı üzerine Rusya'nın İstanbul ortaelçisi Varilde Tamara'nın talebiyle Kostantino Peristiyani, ${ }^{7} 1802$ yılında Kıbrıs'a konsolos vekili olarak atandı (KȘS., 24/32-2; dinç, 2010, s330; Özkul, 2013, s. 268; Demiryürek, 2015, s. 719). Kıbrıslı yazar A. Cemal Gazioğlu, Konstantin Peristiyani'nin Rum asıllı olduğunu belirtmektedir (Gazioğlu, 2000, s. 308). Konuya çalışmasında değinen Özkul, Peristiyani'nin 20 Kasım 1812'de yani Bükreş Antlaşması sürecinde konsolos vekili olarak görevlendirildiğini ifade etmektedir (Özkul, 2013, s. 265).

$\mathrm{Bu}$ husus belgelere, "[...]Rusya devleti tarafindan lâzım görülecek âmme-i mevâki'de konsoloslar ve konsolos vekillerinin nasbina devlet-i aliyye'miz cânibinden ruhsat verilüp dost olan sâir devletin konsolosları i'tibâr olundukları gibi merkûmlar dahi mu'teber tutulalar deyü Rusyaluya i'tâ olunan ahidnâme-i hümâyûnda münderic olduğundan Klbris cezîresine âmed-şod eden Rusya sefâyini ve tüccâr ve âdemlerinin vukû' bulan umûr ve husûsların ru'yet eylemek üzre bundan akdem bâ fermân-ı âlî nasb olunan konsolos vekîli bu def'a hâlik olmağla yerine Kostantino Peristiyani nâm müste'men konsolos vekîli nasb ü ta'yîn olunduğundan bahisle ahidnâme-i hümâyûn şürûtu mûcebince cezîre-i mezbûreye iyâb ü zihâb eden Rusya sefâyini ve tüccâr ve âdemlerinin umûrlarını ru'yet edüp konsolos vekâleti umûruna hilâf-ı şürût-ı ahidnâne-i hümâyûn âhardan müdâhale olunmamak ve himâyet ü slyânet olunmak bâbında emr-i şerîfim recâ ve mersûm sahîh müste'men olduğu hâlde ber mûceb-i ahidnâme konsolos vekîli nasb olunmak fermânım olmağın [...]" (KŞS., 24/32-2) şeklinde yansımıştır.

Peristiyani'nin Rusya'nın Kıbrıs konsolosluğunu daha etkin hale getirmek amacıyla konsolos olarak tayin edildiği tespitini yapanlar da bulunmaktadır. Fransa'nın Mısır'ı işgal etmesi, Kıbrıs'1 Rusya için daha önemli hale getiriyordu (Dinç, 2010, 330). Osmanl1-Rus savaşının başlangıcından itibaren savaş psikolojisi Osmanlı belgelerine yansıyordu. Rusya'nın Kıbrıs’taki konsolosluk faaliyetleri de bundan etkileniyordu. İlişkiler inişli çıkışlı bir hal arz ediyordu. Ayrıca 1802-1806 Osmanlı-Rus savaşının Kıbrıs'a etkileri ayrı bir çalışma ile ele alınmalıdır. Nitekim savaş başlamadan evvel haberleri yayıldığında Kıbrıs muhassılı Hüseyin Efendi'ye gönderilen yazıda Rusya'nın dost devlet olduğu söylenip Kıbrıs’taki Rus tebaa ve tüccarlarına dostça muamele edilmesi emrediliyordu (KŞS., 26/14-2).

Ancak savaşın başlamasıyla üslûp değişmiş, "Millet-i beyzâ-yı İslâmiyyenin öteden beri düşman-ı tabî 'isi olan Moskof keferesi bu def'a dahi bi-gayr-ı hakk bağteten nakz-ı ahd ve i 'lân-ı harb

\footnotetext{
${ }^{6}$ Rusya ile yapılan Aynalıkavak Ticaret Antlaşması daha önceden İngiltere ve Fransa tüccar ve vatandaşlarına verilen hakları, Rusya Devleti tüccar ve vatandaşlarına da veriyordu. Rusya'nın Kıbrıs'taki ticari faaliyetleri bu çerçevede yürüyordu. (KŞS., 18/125-1).

${ }^{7}$ Theophilus C. Prousis, 19. yüzyıla gelindiğinde Rusya'nın Osmanlı topraklarında konsolosluk açtığı yerlerin stratejik noktalar olduğu yorumunu yapar. Öte yandan Rusya konsolosluklarında istihdam edilen hemen hemen tüm personelin, tercüman, kâtip ve diğerlerinin Yunan, İtalyan ve Fransız kökenli olduklarını; bunların Osmanlı kurumları ve toplumu ile olan aşinalığının Rusya Devletince değerlendirildiğini belirtir(Prousis, s.2003, s. 128).
} 
etmiş olduğundan”, Rusya'nın İstanbul elçisi sınır dışı edilmişti. Bu meyanda Kıbrıs'a dışarıdan vaki olacak saldırılar karşısında tedbir alınması Kıbrıs muhassılına emredilmişti (KŞS., 26/24-1). Bunun ardından Rusya'nın İstanbul elçisi ve tebaası ile Kıbrıs'ta bulunan Rusların da 20 gün içinde burayı terk etmeleri istenirken bu durum "Kıbrıs cezîresinde bulunup geri kalan tüccâr ve sâir Rusyaltyı taharrî birle geri kalmış var ise vilâyetlerine def "'şeklinde ifade edilmişti (KȘS., 26, 24-2).

Osmanlı Devleti ile Rusya arasında 1806-1812 yılları arasında cereyan eden savaş esnasında Kıbrıs'tan kovulan Costantin Peristiyani, 1821 yılı yazı başlarında Kıbrıs'a yeniden konsolos vekili olarak atandı (KŞS., 30/140-3) ${ }^{8}$. Peristiyani aynı tarihli diğer bir berat ile de İsveç Devleti adına Kıbrıs konsolosluğuna tayin edilmişti (KŞS., 30/140-4) .

Mora'da 1821 y1lında başlayan Yunan isyanı, Rus konsolosluğunun oldukça faal bir halde olayların içine girmesini sağladı. Konsolos, Ada'da Rum isyanı sırasında dahil bulunan Rumların kovuşturulması sürecinde çok sayıda Rum'un Ada dışına kaçmasını sağladı. Bu faaliyetleri ve 18281829 Osmanlı-Rus Savaşı'nın etkisiyle Peristiyani'nin görevine yine son verildi. Savaşın ardından 24 Nisan 1830'da tekrar Kıbrıs konsolosluğuna getirildi (Dinç, 2010, s. 331; Özkul, 2013, s. 269).

Peristiyani'nin Kıbrıs'taki konsolosluk görevi mahiyeti kadar bağlı bulunduğu devlet açısından da incelemeye değer. Her şeyden önce Rum asıllı olmasını avantaja çevirdiği anlaşılmaktadır. Peristiyani, Rusya ve İsveç devletleri tarafından tercih edilen bir şahsiyet idi. Rusya konsolosluğu görevi sebebiyle Ada'dan çıkması istendiğinde İsveç konsolosu sıfatıyla Kıbrıs'ta kalmaya devam etmişti. Ayrıca 1830 yılında yapılan temettü sayımlarında, diğer ülke konsolosları yanında Peristiyani'nin de adı geçmektedir. Lakin bu sayımda Rusya konsolosluğu kaydedilmezken Peristiyani İsveç konsolosu olarak kayıtlara geçmiştir.

Rusya'nın Osmanlı ülkesinde ticaret yapma hakkı aldıktan sonraki süreçte kendi tebaasından olan şahıslardan başka Osmanlı tebaası gayrimüslimlere berat ve patente vererek onları da kendi tebaalarının sahip olduğu ayrıcalıklı konuma sokma gayreti, 1806 yılında da tartışmalara yol açıyordu. Osmanlı Devleti her ne kadar Osmanlı reayasından üç yıldır Rusya'da oturanlar dışındaki kimselerin Rus tebaası sayılmayacağ 1 üzerinde bir anlaşma yapacak olduysa da, savaş sebebiyle bu sorun 1812 Bükreş Antlaşmasına kadar sürüncemede kalmıştı (Bağış, 1983, s. 84). Rusya'nın berat ve patente aracılığıyla Osmanlı toplumsal katmanlarıyla temasa geçmesi, Mora'da isyan sürecini tetikleyerek geniş kapsamlı ve olumsuz etkilerini göstermeye başlamıştı. Nitekim Rusya'nın himayesinde Yunanistan'ın bağımsız devlet olmasından sonra Ada'da Yunan vatandaşlığı etrafinda yeni meseleler baş gösterdi (Erdönmez, 2013, s. 175-198). Mora'da ilk isyan başladıktan sonra buraya gidip destek veren çok sayıda Rum, Ada'ya Yunan pasaportu ile dönüyordu. Bunlar içerisinde Rus, Fransa, İspanya ve Nemçe tebaası olarak gelenler de vardı. Osmanlı makamlarından bu statülerini kullanarak vergi muafiyetiyle ilgili taleplerde bulunuyorlard. Peristiyani; Marko, Acilov, Giovanni ve Yermilov isimli dört oğluyla birlikte, Ada'ya yabancı ülke pasaportuyla gelen Rumları himaye ediyordu. Ada'dan firar eden Rumları Rus gemileri ile taşıttırıyordu. Ayrıca bu kişileri Osmanlı makamlarına vergi ödememeleri hususunda kışkırttığı Osmanlı resmi belgelerine yansımıştı (Dinç, 2010, s. 331).

Kıbrıs muhassılı Halil Efendi, konsolos vekilinin faaliyetlerinden duyduğu rahatsılılı̆ İstanbul'a iletti. Rusya elçiliği üzerinde baskı yapılarak konsolosun hareketlerinin önlenmesini talep etti. Osmanlı makamlarının Rusya elçiliğine ilettiği mesaj, henüz barış ortamına giren ilişkilerin Kıbrıs konsolosunun davranışları sebebiyle bozulmaması gerektiği yönünde idi. $\mathrm{Bu}$ durumda Rusya elçiliğinin konsolosu görevden azledip oğulları ile Ada'dan çıkartması beklenirken, iş sürüncemede bırakıldı. Elçilik, konsolosa Osmanlı reayasını himaye etmekten vazgeçmesi yönünde bir uyarıda

\footnotetext{
${ }^{8}$ Peristiyani'nin bu defaki tayini sırasında kendisine daha önce verilen 15 Zilkade 1227/20 Kasım 1812 tarihli tayin beratı deftere yeniden yazılmış; altına yeni işlem tarihi konulmuştur.

${ }^{9}$ Peristiyani'nin İsveç konsolosluğu'na ilk tayini 1 Receb 1228/30 Haziran 1813 tarihliydi.
} 
bulunmak ile yetindi. Bu gelişmeler üzerine Peristiyani, Kıbrıs muhassılına Rumlar üzerinde sorun çıkarmayacağına dair taahhüt verdi (Dinç, 2010, s. 331-2). İlerleyen zamanlarda 1842-1856 yılları arasında Marko Santi Rusya'nın Kıbrıs konsolosluğunu yürütürken 1856 yılında Rusya tebaası Vonde Cato bu göreve tayin edildi (Özkul, 2013, s. 269) ${ }^{10}$.

Rusya, XVIII. yüzyıl sonlarından itibaren stratejik yayılma yönünü Akdeniz havzasına çevirmişti. Yüzyılın başından itibaren kimi zaman Osmanlı Devleti ile doğrudan savaşa girerek, bazen de Sırp ve Yunan isyanlarında olduğu gibi Osmanlı gayrimüslimlerinin bağımsız devlet olma süreçlerini destekleyerek büyük bir tehdit oluşturmuştu. Rusya bu stratejik tutumu ile bir tehdit unsuru olarak Osmanlı Devleti üzerindeki etkisini XIX. yüzyıl başlarında da koruyordu.

Bölgesel gelişmeler, Rusya’ya daima konjonktürel politikalar üretme firsatı sunmaktaydı. Mısır Meselesi'nden de bu minvalde istifade etmeyi başarmıştı. Osmanlı Devleti, Mısır Valisi Mehmet Ali Paşa'nın isyanını bastıramayıp dışarıdan destek arayışına girdiği süreçte Rusya önce müttefik olarak Osmanlı hükümetine sağladığı destekle belirgin bir nüfuz elde etti. Ardından İngiltere'nin diplomatik manevra ile araya girmesiyle de, etkisiz kılınmış bir gücü temsil ediyordu. Rusya'nın Osmanlı Devleti ile olan ilişkileri diplomatik olarak sürekli değişkenlikler içerisinde seyrederken Kıbrıs bu dönemde de Akdeniz havzasında önemli bir pazar idi (Demiryürek, 2015, s. 715). Bu durum Rusya'nın Kıbrıs'ta yürüttügü ticaretine ve konsoloslarının diplomatik ve hukukî tavırlarına doğrudan yansımaktaydı.

XIX. yüzyıl Osmanlı Devleti için "En uzun yüzyll" olarak adlandırılır (Ortaylı, 2001). Sırp bağımsızlık hareketi, Osmanlı-Rus savaşı, Mora ayaklanması, Yunanistan'ın bağımsızlığı, Mısır Valisi Mehmet Ali Paşa isyanı gibi hadiseler, kısa sürede devleti yıpratmaya yetecek sonuçlar doğurmuştu. Yüzyılın ilk yarısında Kıbrıs'ta görev yapan Rusya konsolosları bu olayların hemen hemen hepsinde Kıbrıs ölçeğinde etkili oldular ve çeşitli meselelere yol açtılar. Büyük devletlerin Doğu Akdeniz ve çevresindeki faaliyetleri, Kıbrıs'ta bulundurdukları konsoloslarının faaliyetleri üzerinde etkili oluyordu. Rusya'nın Kıbrıs'ta bulunan konsolosları ve tüccarları da diğer Avrupa devletlerinin konsolos ve tüccarları gibi Ada'da çoğu kez başına buyruk hareket etme imkânı elde etmişlerdi.

İngiltere, Rusya, Fransa gibi güçlü devletlerin yanında Yunanistan, İsveç ve Danimarka konsolosları da Kıbrıs'ta yerel düzeyde devletin içişlerine müdahale ediyorlardı. Konsolosların esas görev alanları kendi devletlerinin tebaası olan tüccarların ticari faaliyetlerini gözetmek olmasına rağmen yol açtıkları problemler çoğunlukla bunun dışında, hukukî işlemler olarak ortaya çıkıyordu ${ }^{11}$. Hukuk alanındaki imtiyazlarını geniş açıdan yorumlamaları bunun teknik sebebiydi. Gerçek sebep ise, Osmanlı Devleti'nin içinde bulunduğu uluslararası ve yerel siyasi şartlardı. Rusya'nın Kıbrıs'ta faaliyette bulunan tüccarları ticarî faaliyetlerini yürütürken Rusya konsolosluğu da dönemsel olarak iç işlerine müdahalelerde bulunuyordu. Bu müdahaleler gümrük tarifeleri ve vergileri üzerine olabildiği gibi, yerel mültezimler arasında sürtüşme meydana getirme, Kıbrıs idarecileri ile yakın ilişkiler tesis edip mültezimlerini İstanbul hükümetine şikâyet etme ve bazen de İslâm hukukunun temel kaidelerini zorlayacak girişimler şeklinde görülüyordu. Rusya konsoloslarının XIX. yüzyıl ortalarında Kıbrıs'ta yol açtıkları meseleler, Rusya'nın Ada'da yürüttüğü ticari faaliyetlerinin genel bir sonucu idi.

\footnotetext{
${ }^{10} 1870-1871$ yıllarında Rusya'nın Tuzla'daki konsolosluğunun yine konsolos vekilliği olarak devam ettiği görülüyor. (Salnâme, 1287, s. 83); 1870-1871 yıllarında devletler Kıbrıs'taki konsolosluk ağınıTuzla dışında diğer şehirlere, Mağusa, Leymosun ve Lefkoşa'ya da yaymışlardı. Tuzla'da Amerika, İtalya, Fransa, Belçika konsolos; Rusya, Avusturya, İspanya, İngiltere, Danimarka ve Yunanistan ise konsolos vekili bulunduruyordu. (Salnâme1287, s. 83); Lefkoşa'da Fransa, İtalya ve Yunanistan konsolos memuru bulunduruyordu. Leymosun'da ise İtalya, İngiltere, Yunanistan konsolos memuru; Fransa, Avusturya ve İsveç ise konsolos vekili ile temsil ediliyordu. Mağusa'da Fransız konsolos memuru vardı. (Salnâme 1287, s.84).

${ }^{11}$ Nicolae Jorga, Rusya'nın 1841 Boğazlar Antlaşması itibariyle Osmanlı Devleti üzerindeki vesayetinin bittiğini ve bu tarihten sonraki Osmanlı politikasını, çökmekte olup, kısa bir süre sonra tasfiye edilmesi beklenen bir devletin hamisi rolüne devam etmek isteğine bağlar. Yine Jorga'ya göre Rusya, bu sebeple yoğun bir meydan okumaya girişmiştir. Rusya, uzun zamandır hazırlanmış antlaşmalara veya sadece bir örnek dava bile bulsa, buna dayanarak, bulduğu her firsatta uyarı yazıları göndererek elçileri ve konsolosları aracılığıyla müdahalelerde bulunup emrivakiler yapmaktaydı (Jorga, 2005, s.341).
} 


\section{Kıbrıs Ekonomisinde Görülen Olumsuzluklar: Canlı Hayvan Fiyatlarının Düşmesi}

Rusya'nın, Kıbrıs'taki ticari faaliyetlerinin konsolos tayini ile birlikte 1785 yılında başladığı düşünülebilir. Bu tarihten sonraki faaliyetleri, Kıbrıs Şer'iyye Sicillerinden takip etmek mümkündür. Yüzyılın başlarından ortalarına kadarki süreçte tutulan kayıtlar esas alınarak, bu çerçevede yapılan bir taramada, tespit edilen hususlar, konuyu aydınlatmaya katkı sunacak mahiyettedir. Genel bir tespitle, Rusya'nın Kıbrıs'taki ticari faaliyetlerinin, iki devlet arasındaki siyasi ve diplomatik ilişkilerden fazlaca etkilenen kırılgan bir zeminde devam ettiği görülmektedir. Öte yandan, Kıbrıs Adası ile İstanbul arasında cereyan eden ticari ilişkilerde de Rusya'nın doğrudan etkisi hissedilmekteydi. Kıbrıs Şer'iyye Sicillerine yansıyan ilk ticari faaliyet, savaş yıllarının doğal bir sonucu olarak biçimlenmişti.

1806-1812 Osmanlı Rus savaşı Kıbrıs ahalisi üzerine çeşitli yükümlülükler de getirmişti. Bunlardan birisi ordunun ihtiyacı olan etin buradan karşılanmasıydı. Nitekim 5 Cemaziyelahir1225/8 Temmuz 1810 tarihinde Lefkoşa naibi ve diğer kazaların naibleri ile Kıbrıs muhassılına yazılan fermanda, buradan 3.000 baş koyun ve keçinin satın alınarak İstanbul'a gönderilmesi talep edilmişti (KŞS., 27/99-1).

Bu hususa dair talep, "[...] Dînimizin düşmanı olan Moskov keferesinin hâl ve hareketi ve beher tarafdan memâlik-i mahrûseme hücûm ve küffârın menvî-i zamîri külliyen şiken-beden-i be-rızâ-yı İslâm'a olduğu evvel ve âhir neşr olunan evâmir-i aliyyem tafsîlâtından [...] beher re'si ikişer guruş fì ile Klbrls cezîresinden üç bin re's ağnâm ve keçi fî̀i mezkûr ile mübâya 'a ve îcâb eden bahâsı ve rikâb-ı hümâyûnum kassâbbaşısı yedinde olan mîrî akçeden hîn-i mübâya'alarında der-akab ashâbına edâ ve teslîm olunarak tedârik ve ordu-yı hümâyûnum'a sevk ve mûmâ-ileyhe teslîm olunmak fermânum olmă̆ın [...]" (KŞS., 27/99-1) diye ifade edilmişti.

Rusya ile savaş hali sebebiyle İstanbul'a Rumeli'den toplanan hayvanların üçte biri seferdeki orduya tahsis edilmiş ve bu sebeple açık meydana gelmişti. İstanbul'un ihtiyaç duyduğu koyun ve keçinin tedarik edilmesi için yaklaşık bir yıl sonra yine Kıbrıs'a müracaat edilmişti. Kaptan-1 Derya ve Kıbrıs naibine yazılan ferman ile görev Mehmed Said'e verilirken satın alınacak 2.000 baş koyun ve keçinin İstanbul'a gönderilmesi emredilmişti. Bu hayvanlardan erkek koyunun 70, kısır koyunun 60, toklunun 60, erkek keçinin 60, çebicin ise 40 paradan hesaplanması istenmişti (KŞS., 27/179-1).

Bu talep ve hesaba dair ferman, "[...] Bahr-i Sefid'de vâki' ba'zı cezîrelerden mübâya'ası tertîb olunan ma 'lûmü'l-mikdâr ağnâmdan derûn-ı emr-i şerîfüme mevzû'an irsâl olunan sûret-i defter nâtık olduğu üzre mârru'z-zikr Kıbrls Adası cezîresine tarh ve tahmîl olunan iki bin re's ağnâmı ber-mûceb-i şürût damızlık ve sağmâl ağnâmından olmayarak erkek beher re'si yetmişer paraya ve kisırı altmışar paraya ve toklusu kırkar paraya ve keçinin dahi erkeği altmışar paraya ve çebişi kırkar paraya olmak üzre îcâb eden bahâsı sâ 'î yedinden an-nakd ashâbina i 'tâ olunarak inzimâm-l re'y ve ma 'rifetin ve ma 'rifet-i şer' ve mübâşiri ma'rifetiyle mübâya'a ve tahsîl ve Dersa 'âdetüm'e sevk ve tesyîli esbâbını istihsâle bezl-i cell-i himmet eylemen fermânum olmağın [...]” (KŞS., 27/179-1) şeklinde idi.

Savaşın Kıbrıs üzerindeki olumsuz etkilerinden birisi küçükbaş hayvan sayısında azalma ve buna karşılık fiyatının artması şeklindeydi. Bir yıl arayla Kıbrıs’tan toplam 5.000 baş koyun ve keçi İstanbul'a gönderilmişti. Bunun Ada'daki küçükbaş hayvan varlığı üzerinde etkisi olduğu muhakkaktır. Öte yandan bu tür satın almalarda her ne kadar ödeme yapılsa da bu resmi değerlendirme üzerinden oluyordu. 1810 yılında yapılan alım piyasa fiyatının altında idi. 1811 Eylül'ünde Lekoşa'ya yakın Ortaköy'de 32 adet keçiye 3.600 para fiyat biçilmişti. Bu durumda her birinin fiyat1112,5 para yani 2,81 kuruşa gelirken (KŞS., 27/161-1)hayvan sahipleri hayvan başına 0,81 kuruş zarar etmişti. 
1811 yılındaki alımda fiyatlar daha da aşağıya çekilirken koyun başına ortalama 56,6 para; keçi başına ise ortalama 50 para ödenmişti. Bu da hayvan sahiplerinin keçi ve koyun karışık ortalama $\% 33,3$ oranında zarar etmelerine neden olmuştu.

$\mathrm{Bu}$ yılın Mart ayında verilen narha göre koyun, keçi ve teke etinin kıyyesi 12 paraya satılıyordu (KŞS., 27/126-3).İstanbul'a keçi ve koyun ihracından iki y1l önce, 1809 y1lı Ağustos ayında bir keçinin fiyat1 2 kuruş idi (KŞS., 27/23-1) ${ }^{12}$.

XIX. yüzyıl başlarından itibaren Rusya'nın Kıbrıs'taki faaliyetleri 1806-1812 savaşı ile 18281829 savaşlarının etkisi altında cereyan etti. 1813 yılından itibaren Rus tüccarlar Kıbrıs'ta muahede çerçevesinde ticaret yapmaya devam ettiler (KŞS., 28/107-2). İki devlet arasındaki normalleşme süreci Rus diplomatlar tarafindan başarılı bir biçimde normalleştirildi ve hatta Osmanlı bürokrasisi üzerinde tesir edecek bir imkan haline dönüştürüldü. Rus diplomatlar, savaş sonrası ilişkileri“dostane” kavramı ile niteliyorlardı. Bu durum Osmanlı makamlarının Rus yetkililerle yaptıkları yazışmaların üslûbuna da yansımıştı. Nitekim Rusya hakkındaki değerlendirmeler 1819 yılı yazında, oldukça yumuşamış biçimde “Devlet-i Aliyyem 'in Rusya Devleti dost-ı ehabbı olub”, şekline dönüşmüştü (KŞS., 30/18-1).

Ancak kısa süre sonra Ruslar bu nezaket dilinin semeresini almak üzere harekete geçtiler. Rusya'nın İstanbul ortaelçisi Baron de İstergonof, Osmanlı idaresine başvurarak Kıbrıs muhassılını şikâyet etti. Şikâyet konusu doğrudan Rus tüccarların adadan ihraç maksatlı yaptıkları ticaret hakkında idi. Şikâyetin neticesinde Ruslar ticari imtiyazlarını genişlettiler. Ada'daki Osmanlı iç ticaret ağının sınırlarını zorlayarak doğrudan Kıbrıs içlerinden, üreticiden mal alma hakkını teyit ettirdiler ${ }^{13}$. Bununla ilgili bir sürtüşme harnub ticareti vesilesiyle ortay acıkmıştı.

Rus tüccarlar, Kıbrıs'ta 1818 yılı içerisinde doğrudan üreticiden mal almakta zorluklarla karşılaşıyordu. Bunun sebebi yerel idarecilerdi. Osmanlı yerel idarecileri Rus tüccarların doğrudan doğruya üreticiden mal alma süreçlerine müdahil oldular. Mahsulü köylülerden doğrudan kendileri toplayıp bir nevi satıcı durumuna geldiler. Kıbrıs'ta görev yapan muhassılların bu durumu istismar ederek öne çıktıkları söylenebilir. Özellikle harnub ticaretinde bu şekildeki bir sorun ortayaçıktı. Rus tüccarlar Kıbrıs'tan harnub satın alıyordu. Harnub bu dönemde Kıbrıs'tan ihraç edilen en önemli mahsul idi. Rus tüccarlar harnubu doğrudan köylülerden satın alabilirdi. Lakin Muhassıl, köylülerden zorla beher kantarını "Cebren" 4-5 kuruşa satın alıp Rus tüccarlara 12 kuruştan satıyordu. Onlar da gemilerinin boş dönmesindense mecbur kalıp bu fiyattan satın alıyorlardı. Kıbrıs yetkililerine Rus tüccarların diledikleri yerden harnub satın almalarına kimsenin müdahale etmemesi gerektiği bildirildi (KŞS., 30/18-1).

Harnub ticaretine dair husus belgelere, “[...] Rusya tüccârının öteden berü olugeldüği üzre köylülerden harnûb iştirâ eylemelerine Kıbrıs muhassılı esbak cer-i menfa'at zımnında ızhâr-ı mümâna'at ederek beher kantârı dört beş guruşa köylülerden kendüsi cebren alup tüccâr-l mersûmûna on iki guruşa teklîf eylediği ve cezîre-i mezbûreden Rusya diyârina irsâl olunmak üzre ihrâc olunan emvâl hemân harnûba münhasır olduğuna binâ'en tüccâr-ı mersûme sefineleri tehîavdet etdirmemek içün matlûb olan gerân-bahâ ile muhassildan harnûb ahzina mecbûr olduklarından [...]” (KŞS., 30/18-1) şeklinde yansımıştı.

\footnotetext{
${ }^{12} 25$ Cemaziyelahir 1224/7 Ağustos 1809 tarihli mahkeme kaydına göre, Hanife bint-i Osman, eski kocas1 İsmail aleyhinde dava açtı. İddiasına göre 20 adet keçisini toplam 40 kuruşa satmıştı. Bu satışa izni yoktu.

13 XVII. yüzyılda yabancı tüccar Ankara, Bursa gibi şehirlerde ajanlar bulundurarak ihraç edecekleri maddeleri üretim yerlerinde satın alıyor idilerse de bunu bir iç ticaret konusu yapmıyorlardı. Fakat XIX. yüzyılda durum değişti. Yabancı tüccarın önce toptan ticarete, 1838 Balta Limanı Muahedesi sonrasında ise bu muahedenin sadece İngilizcesinde mevcut olan, "oradaki her türlü ticaret" ifadesine dayanarak, Osmanlı Hükümeti'nin itirazlarına ve muahedenin bu maddesini değiştirme çabalarına rağmen, perakende ticarete de başladıkları görülmektedir(Kütükoğlu, 2018, s.359).
} 


\section{Savaș Psikolojisinin Ticari İlişsilere Yansıması}

1806-1812 savaşının ardından Rusya ile ilişkilerin normalleşmesi Ada'daki Türk görevlilerle Rusya vatandaşlarının arasındaki iktisadi ilişkilere de yansımıştı. Kıbrıs defterdarı Seyyid Hasan Ağa bin Edhem Ağa 1820 yılında vefat ettiğinde ona borcu olanlar arasında Rusyalı Haci Yerolmi de bulunuyordu. Yerolmi'nin eski defterdara 450 kuruş borcu vardı (KŞS., 30/121-3).

Bu borç bilgisi, "Kıbrıs cezîresinde mahrûse-i Lefkoşa mahallâtından Ayasofya mahallesinde sâkin olup cezîre-i mezbûre defterdârt iken otuz üç senesi evâhir-i Şevvâli'nde vefât eden es-Seyyid Hasan Ağa ibn-i Edhem A ̆ga nâm müteveffânın verâseti [...] Der-zimmet-i Rusyalı Haci Yerolmi 450 guruş [...]" (KŞS., 30/121-3) olarak kayttlarda yer almaktayd1.

$\mathrm{Bu}$ arada 1822 yılı sonlarında, 1821 yılında Mora'dakiisyanın doğal bir uzantısı olarak Kıbrıs'taki kargaşa devam etmekteydi. Bilhassa eşkıyalık faaliyetleri devletin önlemeye çalıştı̆̆ meselelerin başında geliyordu. Bu maksatla da Rum eşkıyasının faaliyetlerine karşı tedbir amacıyla Kıbrıs'taki kalelerin savunması güçlendirildi. Kıbrıs muhassılı Mehmed Ağa ve ada önde gelenleri, kalelerde ihtiyaç duyulan barutu temin yoluna girdiler. İstanbul'dan bu konuda bir tedarik imkânı aranmaksızın adada bulunan Rusya konsolosundan barut satın alınması yoluna gidildi. Bu çerçevede Rusya konsolosundan iki defada toplam 1.297 kıyye kurşun alınarak 2.594 kuruş ödendi (KŞS., 30/178-2).

Belgeye kayıtlı hükme göre, "Kıbrıs cezîresinde kâ'in kılâ'-ı hâkâniyede mühimmâtın killet ü nedreti derkâr ve Rum milleti eşkiyâlarından zuhûr eden şerr ü fesâda mebnî merâsim-i hazm u ihtiyâta ri âyet vâcibe-i zimmet idügini nümû-dâr idüğinden başka bu bâbda rehâvet ve tekâsül tecvîz olunmayarak emr-i muhâfaza ve müte'ennîde ikdâm-ı tâm olunmak husûsunda peyderpey bâ-evâmir-i aliyye tenbîh u te'kîd buyurulduğu hilâlde knlâ'-ı merkûme dizdârânı ve ahâlî ve ihtiyâr ve zâbitânı taraflarından mühimmât kallet ü nedretinden bahs ederek mühimmât istid'âlarına binâ'en ma'rifet-i şer'-i şerîf ve hâlâ cezîre-i mezbûrede muhassll-ı emvâl olan silâşörân-ı hazret-i şehriyârîden sa âdetlü Mehmed Ăga kulları ma'rifetleri ve vücûh-ı cezîre ittifầk ve iltimâslarlyla mukaddem ve mu'ahhar iştirâ ve kulâ'-ı merkûmede vâki' cebehânelere vaz've tertîb ve isrâ olunan barut-l siyâh ve kurşun ve mühimmât-l sâ'ire defteridir ki beyân olunur [...]Rusya konsolosundan iki def'ada alınan kurşun 1.297 kiyye, fi 2.594 guruş [...]" (KŞS., 30/178-2) ödenmişti.

1821 yılındaki Mora isyanından sonraki süreçte Osmanlı idarecilerinin Rusya tüccarlarına karşı tutumlarındaki değişim, onların adaya ithalat yapan tüccarlar listesinden istiskal olmaları sonucunu da doğurmuştu. Ancak Rus tüccarların gümrük listelerinde yer almamış olmaları Rusya mahreçli malların adaya indirilmesine engel olmamıştı. Ruslar bu krizi aşmanın formülünü bulmuşlardı. Bilhassa bu dönemde adaya yapılan ithalatta Rus malları görünmesine rağmen, bunları Kıbrıs'a getirenler Fransızlardı. Rusya tüccarları ezeli rakipleri İngiltere ve Fransa tüccarları gibi Kıbrıs'ta ticaret yapıyorlardı. XIX. yüzyıl başlarında Kıbrıs'a ithal edilen mallar arasında Rusya mahreçli olanlar da vardı. Ancak bu dönemde Rus malları Kıbrıs'a Fransız tüccarları tarafından getirilmekteydi. Osmanlı idarecileri de esasen bu süreci zımnen tasdik etmekteydiler. Zira Fransız tüccarlara verilen gümrük tarife defterlerinde Rusya kökenli malları görmek mümkündü. Nitekim Tuzla kadısı ile Tuzla gümrükçüsüne 1816 yılı Aralık ayında bildirilen gümrük tarifesi, Fransız tüccarların Osmanlı ülkesine getirecekleri malların listesini içermekteydi.Gümrük tarifesine göre Rusya mahreçli olarak Tuzla iskelesine indirilen mallar, "Âhen-i hâmm-ı Rusya, Bagana-i Rusya, Semmûr-ı Rusya, Rusya tilkisi, Rusya'nın kebîr mismârı, Semmûr hurdası Rusya, Rusya'nın muşamma 'lık kirpası, Rusya 'nın ravendik ta 'bîr olunur sağîr muşamma 'lık kirpası, Rusya'nın cildârini”' (KŞS., 29/97-1) idi.

Rusya tüccarları, yasaklı sayıldıkları bu süreçte adaya mal ithal etme konusunda diğer ülke tüccarları ile işbirliği sistemi geliştirdiler. Fransız tüccarlar yanında Sardunyalı tüccarlar da bu sitemde yer almaktaydı. 1825 Nisanında Tuzla kadısı ve Tuzla gümrükçüsüne yazılan gümrük tarifesine göre, Rusya mahreçli malları Kıbrıs'a Sardunyalı tüccarlar getirmekle birlikte bu mallar, "[...]Kırmızı Rusya dilküsi, Mismâr-ı Rusya, Kendir ve tel-i hâm-ı Rusya, Alaca-i Rusya, Ensiz alaca-i Rusya, 
Katranlı beyâz halat-ı Rusya, Tohm-ı tannân-ı Rusya, Telatin-i Rusya, Şem'-i revgan-ı Rusya, Rusya semmûr hurdesi, Rusya'nın donuk ta 'bîr olunur să̆îr muşamma 'lık kirpas, Rusya'nın koçanlı adalığl, Rusya'nın at kılı koçansız, koçanlı ve koçansız sağîr kuyruğu Rusya, Keçi kılı Rusya, Bagâne-i Rusya, Sağrı-i Rusya, Revgan-ı çerviş ve don-ı Rusya, Rusya'nın cild-i erneb [...]” (KȘS., 31/112-1, 113, $114,115)$ olarak çeşitlilik göstermekteydi.

Rusya mahreçli bu malların tamamı veya bir kısmının Kıbrıs'a getirilip getirilmediğine dair ilgili kayıtlarda bilgi yoktur ancak Tuzla naibi ve gümrükçüsüne bu listelerin verilmiş olmasından Ada'ya bu malların da ithal edildiği farz edilebilir. Öte yandan Rusya mahreçli oldukları isimlerinden anlaşılan bu malların, Rusya tüccarları değil de Fransa tüccarları tarafından ithal edilmesi, bu dönemde Osmanlı Rusya ilişkilerinin kopmasıyla ilgili olmalıdır. Keza Kıbrıs’ta da aynı durum söz konusu olmalıdır ki Kıbrıs konsolosu ve adamları Ada'dan çıkartılmışlardı.

1828 yılı yazı başlarında Rusya'nın Boğdan üzerine savaş açması bu süreçte İstanbul'dan Kıbrıs'a gönderilen resmi belgelere yansımaya devam ediyordu. Daha önceki barış döneminde belgelere Rusya hakkında yansıyan iyi niyet ve dostluk ifadeleri zıt bir biçime dönüşmüştür. $\mathrm{Bu}$ dönemdeki yazışmalarda Rusya açıkça Rumları, Osmanlı idaresinden ayırmaya çalışan bir devlet olarak tanımlanmaktaydı. 1828 Mayısında Kıbrıs muhassılı Ali Rûhi'ye yazılan bir emir, Ada'da Rusya ticareti ve konsoloslarına bakışı etkileyeceği muhakkak olan bir içerik taşıyordu (KŞS., 33/52$1)$.

Belgede bu durum, "[...] Kıbris muhassll Ali Rûhi zide mecdühû tevkî'-i refi' 'i Hümâyûn vâssl olıcak ma 'lûm ola ki; cümleye ma 'lûm olduğu üzre Rusyalu evvel ve âhir dîn ü devlet-i aliyye-i Muhammediyye hakkinda derkâr olan husûmeti icrâya mukaddime olmak üzre Rum milletine serbestiyet tahsîli garaz-ı fâsidiyle izhâr eylediği inâd ve ısrârı ancak umûm millet-i İslâmiye hakkinda koruduğu sûu-i kasd ve ihânet dâ 'iyesinden nâş̧ıิ olarak ya 'ni bunun üzerine i lân-ı harb eylediği hâlde evvelkiler gibi hudûd ve memleket da vâsı olmayup mücerred dîn-i mübîn gavgası olacağına mebni [...]”" (KŞS., 33/52-1) şeklinde açıkça belirtilmiştir.

İstanbul'dan Kıbrıs'a gönderilen 15 Mayıs 1828 tarihli emirde Rusya ile ilişkilerin alenen düşmanlık zemininde olduğu ve bunun da esasen Rusya'dan kaynaklandığı belirtiliyordu. Seçilen ifadede Rusya öteden beri sadece Osmanlı Devleti ve tebasının değil, tüm Müslümanların düşmanı olarak nitelendiriliyordu. Böylelikle Osmanlı Devleti'nin Rusya hakkındaki diplomatik tavrı düşmanlık olarak nitelendirilmekle kalmayıp aynı zamanda tarihsel bir derinliğinin olduğu da kayıtlara geçmişti. Bu tasnifin taşra idarecilerine yansıması da elbette Rusya tüccarları ve konsolosları aleyhineydi. Rusya'nın düşmanlığ emirde, "Rusyalu öteden berü millet-i İslâmiyenin düşman-l tabî 'îsi olduğu evvel ve âhir bilinmiş ve bu def'a dahi bu vechile memâlik-i mahrûseme tecâvüz ve tahattî ile bi'l-fi 'l i 'lân-ı harb ve izhâr-ı husûmet eylemiş olduğuna mebni”' (KŞS., 33/52-1) ${ }^{14}$ şeklinde ifade edilmişti.

1829 yılı sonbaharında sürmekte olan savaşın bitmesi ve Rusya ile barışın yenilenmesi üzerine belgelerde Rusya hakkında kullanılan dil yeniden değişmeye, düşmanlık içeren üslup yerini barış mesajlarına bırakmaya başlamıştır. Kıbrıs muhassılı Ali Rûhi'ye yazılan fermanda, "Devlet-i aliyyemle Rusya devleti beyninde muhârebe ve muhâsamayl mûcib bir hâlet kalmayup emr-i musalaha in 'ikâd-pezîr olmuş olduğu" belirtiliyordu. Barışın doğal sonucu olarak Rusya tüccarlarına karş1 düşmanca tavır sergilenmemesi de "Bundan böyle devlet-i müşârun-ileyhânın züvvâr ve adam ve tüccârlarına taraflarınızdan hâsmâne mu'âmele olunmayup izhâr-ı levâzım-ı dostî ve musâfâta ihtimâm ve dikkat birle" ifadesiyle emredilmişti (KŞS., 33/174-1).

\footnotetext{
${ }^{14}$ Rusya'nın Tuna'yı geçip Silistre, Varna ve Şumnu'ya saldırması üzerine, Kıbrıs'a da sureti gönderilen emirde, on iki yaşından yetmiş yaşına kadar eli silah tutan her Müslümanın savaşmak üzere orduya katılmaları isteniyordu (KŞS., 33/87-1).
} 


\section{Diplomatik İlişkilerdeki Normalleşmenin Ticarete Yansıması}

1828-1829 savaşından sonra Kıbrıs'ta Osmanlı-Rus ilişkileri tekrar normalleşmeye başlamış, birkaç y1l içerisinde, 1833 yılından itibaren ise normal bir biçim almıştı. Bu normalleşmede iki devletin birbirlerinden elde ettikleri menfaatlerin etkisi vardı. Rusya açısından, 8 Temmuz 1833 tarihli Hünkâr İskelesi Antlaşması ile Osmanlıya kabul ettirdikleri Rus korumacılığının sağladığı nüfuza karşılık Osmanlı açısından Kavalalı Mehmed Ali Paşa gailesi karşısında temin ettiği desteğin etkisi vardı (Beydilli, 1998, s. 488-490).

Kavalalı Mehmed Ali Paşa gailesinin başlangıcında Rusya'nın Osmanlı devleti yanında yer alması, Rusya'ya Osmanlı Devleti üzerinde göreceli bir nüfuz kazandırmıştı. 1835 yılına gelindiğinde bu nüfuzlu ruh hali Rusların Kıbrıs'ta daha önce pek karşılaşılmamış taleplerle yerel idarecilerin huzuruna çıkmalarını sağladı. Bu talepler ticaret içerikli değildi. Ruslar Kıbrıs'ta define aramak için izin istiyorlardı. Bu konuda ilginç bir örnek vaka; Rusya tebaası Nikola Vitale isimli kaptanın Kıbrıs muhassilından define arama izni istemesidir. Rusyalı kaptan Vitale, Ada'da 3-4 cami, 5-6 hamam, 15 hane ve kale içinde, Venedik ve Ceneviz dönemlerinden kalma define arayacaktı. Şayet bulursa definenin beşte biri kendisinin olup geri kalanı Darbhâne-i Âmire'ye verilecekti. Musa Ağa yanına yardımcı ve mübaşir olarak verilmişti. Devlet, define gelirlerini faydalı buluyordu (KŞS., 35/115-2).

Bu husus belgelere, "Klbrıs cezîresinde üç dört câmi '-i şerîf ve beş altı hammâm ve on beş hâne ve kal'a derûnlarının ba'zl mahalleriyle cem'an otuz iki mahalde Venedik ve Ceneviz vaktinden kalmış külliyetlü nükûd medfûn olduğunu Rusya tebe'asından Nikola Vitale nâm kapudân yedine geçmiş olan ba 'zl evrâkdan istidlâl eylediğini ve mahallerinde ihrâcı irâde-i seniyye buyurulur ise ücret-i hafriyye vesâ'ir bu makûle vukû'u muhtemel olan masârlf cümleten kendi tarafindan rü'yet olunarak ihrâc olunacak emvâlden kendüye münâsib mikdâr hisse ifrâzzyla mâ'adâsı Devlet-i Aliyye'ye râci olmak üzre tesviyesini ifâde ve bu mâddeye kuvve-i kalbî olduğundan kendüye i'timâd ve müsâ'ade buyurulmasin istid'â etmiş ve müte'allık buyurulan irâde-i seniyye mûcebince Darbhâne-i Âmire nâzırl efendi tarafindan kapudân-ı mersûm celb ile bi'l-cümle masârıfât mersûm tarafindan görülmek ve zuhûr edecek mâldan beşde bir hissesi kendüye ve mâ'adâ dört hissesi Darbhâne-i Âmire'ye verilmek ve evvel-emrde açıda bir mahal hafr ile bir şey zuhûr eder ise diğer mahal hafr olunmaksızın ol mahallin menâfi inden beşde bir hisâbiyla hissesi kendüye verilüp ba 'dehû âhar mahal hafr olunmak ve bu vesîle ile kimesneye gadr u zarar tecvîz olunmamak ve tarafinızdan birer mu'temed âdemler terfik ile dâ'imâ beraber bulunmak üzre söyleşilüp karâr verilerek konturato senedine rabt kilınmıs ve nâzır-ı mûmâ-ileyh tarafindan dahi bu husûsa Musa Ağa ta yîn ve mersûma terfik kalınmış olup [...] Mersûmun ifâdesi vechile mahâll-i mezkûrede öyle define zuhûr etdiği hâlde işe yarayacağı derkâr olduğu misillü bu vesîle ile beyhûde bir takım cevâmi "ve hammâmların dahi tahrîbi lâylk olmayacağından ana göre evvel-emrde boşda olan mahallerin hafriyla [...]” (KŞS., 35/115-2) şeklinde yansımıştı.

Vitale'nin Kıbrıs muhassılı es-Seyyid el-Hâc Mehmed Ağa'nın bilgisi dâhilinde Mağusa'da 16, Lefkoşa'da 35 ve Evdim'de 3 olmak üzere 54 mahâlde kazı yaptı̆̆ bu yerler liste halinde İstanbul'a bildirildi (KŞS., 35/116-1). Rusyalı Kaptan Vitale'nin define aramak üzere izin istediği yerler, son derece dikkatli bir çalışma neticesinde tespit edilecek mahiyette ayrıntılar içermektedir. Burada önemli olan husus, Rus kaptanın buralarda define bulup bulamamasından ziyade böylesine teferruatlı bilgilere ulaşacağı bir istihbarat ağına sahip olmasıdır. Arama yapılacak yerler; kale içi, bahçe, cami bahçesi, deniz kıyısındaki heykel, Mevlevihane bahçesi, müslim ve gayrimüslim Osmanlı tebaasına ait evler gibi geniş bir yelpazede görünüyordu.

Arama yapılacak yerler, "Magosa'da hafr olunan mahallât beyân: $\dot{I}_{c} \mathrm{kal}$ 'a derûnunda 5 mahal, Taşrada kenîsede 2 mahal, Tophâne mahallesi mescid-i şerifinde 2 mahal, Mahalle-i mezkûrede liman-ı reîs hânesinde 1 mahal, Merkûmun bağçesi verâsında kenîsede 2 mahal, deniz klylsında dev resmi olan taş yanında 2 mahal, Canpolat Paşa civârında Mevlevîhâne bağçesinde 2 mahal. Lefkoşa'da hafr olunan mahallât beyân: Ömeriyye mahallesinde Tercümânoğlu Yanko'nun bağçesinde 7 mahal, Ayasofya câmi '- $i$ şerîfi önünde 3 mahal, Ayasofya mahallesinde Papas hânesinde 3 mahal, Kafesli kenîse mahallesinde Toğose zimmînin arsasinda 4 mahal, Mahalle-i mezbûrede Kalaycı Dimitri zimminnin hânesinde 3 mahal, Ömeriyye câmi ${ }^{\prime}-i$ şerîfinin içinde ve önünde 2 mahal, Ömeriyye câmi ${ }^{-}-i$ şerîfinde yağ mahzeninde 2 
mahal, Arablar câmi'-i şerîfi civârında hâlî arsa ve derûnunda olan kuyuda 1 mahal, Berber İbrahim hânesinde olan kuyuda 1 mahal, Bayrakdar câmi 'i şerîfi civârında hisâr dibinde 1 mahal, Çakmaklı kenîse mahallesinde Alâiyeli Çirkako'nun hânesinde 3 mahal, Değirmenlik'de Penaye kenîsesi yanında 2 mahal, Mesarya kazâsinda Ayanapa kenîsesindel mahal, Kazâ-yl mezbûrede Ayayorgi kenîsesi derûnunda 1 mahal, Evdim karyesinde Eski kenîsede 1 mahal, Kazâ-yl mezkûrede Elheron(?) karyesinde Kağıdkubbeli kenîsesi derûnunda 2 mahal” (KŞS., 35/116-1) olarak kayitlara geçmişti.

Define arama izninden sonra, taraflar arasındaki ilişkiler gittikçe güvenli bir döneme girmişti. Hatta Osmanlı idarecileri, Kıbrıs İstanbul hattında cereyan etmekte olan gemi taşımacılığı işini Rus gemicilere vermekte sakınca görmemişlerdi. 1834 yılı mahsulünden Kıbrıs'tan İstanbul'a buğday ihraç edilmesi gerekmişti. Kıbrıs'tan İstanbul'a sevk edilecek buğdayın nakliyesinde İngiltere ve Avusturya gibi kaptanların gemileri yanında iki Türk gemisi kullanılırken, Rusya gemilerinden de istifade edildi. Kıbrıs muhassılı es-Seyyid el-Hâc Mehmed Ağa satın aldığı buğdayı Rusyalı Penayi Rakopollo gemisiyle İstanbul'a gönderdi. İstanbul'a gönderilen buğday, Tuzla'dan 1.895 kile, Baf'tan 9.605 kile ve Leymosun'dan 500 kile olmak üzere toplam 12.000 kile idi (KŞS., 35/106-1). Kıbrıs'ta çeşitli ambarlardan toplanarak İstanbul'a gönderilen buğday miktarı 52.922 kile ve 585.301 kuruş tutarında idi. Rus gemileri burada yapılan nakliyatın \%22,67'sini karşılamışt ${ }^{15}$.

Ada'dan İstanbul'a gönderilen buğday, "İşbu bin iki yüz elli senesine mahsûben sekene-i Dâru'l-hilâfeti'l-aliyye idâreleriyçün cezîre-i mezbûre muhasılı Dergâh-ı Âlî kapucıbaşılarından sa'âdetlü es-Seyyid el-Hâc Mehmed A ̆ga ma'rifeti ve ma'rifet-i şer'le mübâya'ası tertîb ve matlûb-ı şâhâne buyurulan zehâyirden bi'l-istîcâr irsâl olunan sefâyine tahmîl ve bâ-i'lâm Dersa 'âdet'e Anbâr-l Âmire'ye irsâl olunduğu ber-vech-i âtî beyân [...] Rusyalı Penayi Rakopollo sefinesiyle Tuzla'dan 1.895 kileBaf'dan 9.605 kile, Leymosun'dan: 500 kileCem 'an bâ-i 'lâm irsâl olundu, 12.000, Ceman 58.125 kile” (KŞS., 35/143-1) olarak kaydedilmişti.

$\mathrm{Bu}$ nakliyattan bir yıl sonra 1835 yılında ikinci bir nakliyat gerçekleştirildi. $\mathrm{Bu}$ yılın mahsulünden Kıbrıs'tan İstanbul ahalisinin ihtiyacı için toplam 79.818 kilebuğday ihraç edildi. Buğdayın Mağusa ve Tuzla'dan olan 7.118 kilesi Rusyalı kaptan Pavlo Kefalano gemisiyle nakledildi (KŞS., 35/167-1). Bu defa toplam nakliyatın \%8,91'i Rusya gemisi ile yapıldd ${ }^{16}$.

$\mathrm{Bu}$ nakliyat da, "işbu bin iki yüz elli bir senesine mahsûben sekene-i Dâru'l-hilâfeti'l-aliyye lâzımesiyçün cezîre-i Kıbrıs'dan cezîre-i mezbûre [muhassılı] Dergâh-ı Âlî kapucıbaşılarından sa 'âdetlü es-Seyyid el-Hâc Mehmed Ăga ma'rifetiyle mübâya'ası tertîb ve fermân-ı âlî buyurulan hintadan Dersa'âdet'e Anbâr-ı Âmire'ye bâ-i 'lâm gönderilmiş olan hinta-i mübâya'a beyân [...]Rusyalu Pavlo Kefalano sefinesiyle Magosa'dan 3.382 kileTuzla'dan: 3.736 kile” (KŞS., 35/167-1) olarak kayıtlara geçmiştir.

Rusyalı tüccarlar, 1835 yılına gelinceye dek Kıbrıs'ta kahve ticareti de yapıyordu. Bu yıl kahve gümrüğüne zam yapıldı. 1249 yılı Martı ile 1250 yılı Şubatı arasındaki bir yıllık dönemde Tuzla İskelesi'nden mürûr eden kahve miktarının belirtildiği listede "Bu sene Rusya tüccârl zuĥ̂r etmediği " belirtiliyordu (KŞS., 35/127-2) ${ }^{17}$.

1 Zilhice 1251/19 Mart 1836 yılı gümrük kayıtlarında, kahve ihraç eden tüccarlar listesinde adı geçmesine rağmen "İ̧̧bu sene dahi cezîre-i mezbûreye Rusya tüccârı vurûd etmemişdir" ifadesi yer

\footnotetext{
${ }^{15} \mathrm{Bu}$ dönemde Kıbrıs’tan İstanbul'a toplam 52.922 kile buğday gönderilmişti. Mağusa ambarından İngiltereli kaptan Spiroban gemisiyle 9.422 kile, Nemçeli Kaptan Mankoviç gemisiyle 12.000 kile, Gerzeli Arif kaptan gemisiyle 8.288 kile; Tuzla ambarından Gerzeli Arif kaptan gemisiyle 1.212 kile, Mehmed kapudan gemisiyle 5.203 kile, Rusyalı kaptan gemisiyle 1.895 kile; Poli ve Lefke ambarlarından Tercümânoğlu Yanko kefâletiyle "bu tarafdan bi'l-istîcâr" Kaptan Spiro Antonyo gemisiyle 10.000 kile; Leymosun ve Baf ambarlarından yine Rusyalı kaptan gemisiyle taşınmıştı. Gemilerin toplam masrafı ise 585.301 kuruştu (KŞS., 35/143-1).

16 Tuzla İskelesi ile İstanbul arasında buğday taşıyan 9 gemiden 3 tanesi Müslüman kaptanlara aitti. Bağdadlıŏglu Memiş Kaptan 9.500 kile, Laz Hasan gemisi 7.600 kile, Sinoplu Süleyman kaptan gemisi 10.000 kile buğday taşımıştı. Müslüman kaptan gemileri toplam 27.100 kile yük alarak nakliyatın \%33,95'lik kısmını karşılamışlardı. İşin büyük kısmı yabancı kaptanların elindeydi. Hesaplama KŞS., 35/167-1'e göre yapılmıştır. Bu oranlar Tuzla limanından gelir elde etme oranı hakkında anlık ipucu vermektedir.

${ }^{17} 11$ Zilkade 1250/11 Mart 1835 tarihli kayıta istinaden; Tuzla gümrüğünden geçen kahveden 4.427 kuruş, 20 para gümrük vergisi alınmıştı.
} 
alıyordu (KŞS., 36/47-2). 1251 yılına mahsus yapağ1 vergisi defterinde, "Cezîre-i mezbûreye Rusya tüccârı gelmemişdir” (KȘS., 36/106-2) ibaresinden yine Rusya tüccarının olmadığı görülmekteydi.

Balta Limanı Antlaşmasından önceki aylarda, Osmanlı Rusya ilişkileri her iki taraf açısından da olumlu sayılacak bir zeminde cereyan etmekteydi. 1838 y1lı Nisan'ında "Bahr-i Sefíd Boğazı'ndan Anadolu sâhiliyle nihâyetine varınca vâki “ kazâların kuzât ve nüvvâbı efendiler"e hitaben yazılan bir evrakta, Rusya'dan İstanbul ve sair yerlere gemilerle gelecek Rusya Devleti tebaasından ziyaretçi ve tüccarlara iyi davranılarak gerekli kolaylığın gösterilmesi emredilmişti (KŞS., 36/143-1).

\section{Tanzimat'ın Ticari İlişkilere Yansıması ve Gümrük Tarifelerinden Kaynaklanan Sorunlar}

Osmanlı Devleti idarecileri, 1840 yılı başlarında, uzun zamandır dâhili ve harici ticarette İngiltere ve Fransa gibi dost devletlerin tüccarlarına tanınan imtiyazların ekonomi üzerindeki olumsuz neticelerinin farkındaydılar. Hükümet 29 Cemaziyelevvel 1256/29 Temmuz 1840 tarihinden itibaren, Kıbrıs Muhassı1ı Osman Bey, Kıbrıs timarlı süvârî mîralayı, umûr-1 zabtiye me'mûru Mustafa Bey ve Lefkoşa nâ'ibine bir emir göndererek adada tatbik edilen gümrük vergilerinde yeni bir düzenlemenin başlayacağını bildirdi (KŞS.,38/128-1).

Emirde, ülkenin çoğu yerinde tatbik edilmeye başlanan Tanzimat'ın tüm tebaanın vergi uygulamaları açısından da eşit tutulması gerektiği vurgulanmaktaydı. Bu suretle tebaanın her türlü refah ve asayişleri sağlanabilirdi. İngiltere ve Fransa gibi dost devletlerle süregelmekte olan ticari ilişkilerde, bu devletlerin tebaa ve tüccarlarına verilen imtiyazlar yeniden ele alınıp düzenlenmişti. $\mathrm{Bu}$ ülke tüccarlarından, Osmanlı ülkesinden satın alıp Avrupa'ya ihraç edecekleri emtia ve eşyayı iskelelere indirdiklerinde, yenilenen tarifeye göre $\% 9$ amediye ve gemilerine yükledikleri zaman $\% 3$ reftiyye gümrüğü alınmaktaydı. Aynı şekilde Osmanlı ülkesinden satın alıp yine buralarda satacakları emtianın resm-i gümrük ve masdariyyesi de Osmanlı tebaasından alındığı miktar kadar olacaktı. Müslüman tüccardan $\% 4$, gayrimüslim tüccardan masdariyye dişında $\% 5$ resm-i gümrük ve resm-i ihtisab alınmaktaydı (KŞS.,38/128-1). Bu düzenlemeyi içeren emir ilgililere gönderilmişti.

Bu emirin içeriği, "[...] Memâlik-i Mahrûse-i şâhânemin ekser mahallerinde icrâsına mübâşeret olunmuş olan Tanzîmât-ı Hayriye usûlü iktizâsinca kâffe-i teb'a ve re âyâ-yı Saltanat-ı Seniyyem vergü husûsunda siyyân tutularak her dürlü refâh ve âsâyişleri esbâbı istihsâl olunmakda olduğu misillü vâridât-ı mukarrere-i kadîme ve mülkiyeden ve ahâlî ve teb'a ve tüccâr-ı Saltanat-ı Seniyyem'in edâsı müretteb zimmetlerinden olan gümrük rüsûmâtında dahi usûl-i mütesâviye husûlüyle bi-mu'âveneti'llâhi te 'âlâ Memâlik-i Mahrûse-i şâhânemde teksîr-i ticâret ve teshîl-i kisb ü kâr ve menfa'at vesâ'il-i mukteziyesinin dahi istikmâli mültezim bulunmuş olup şöyle ki; Ingiltere ve Fransa devletleri vesâ' ir ba 'zl düvel-i mütehâbbe ile bundan mukaddem müceddeden akd ve tanzîm olunan mu âhede-i ticâret şerâ'itinden olmak üzre düvel-i müşârun-ileyhim tüccâr ve teb 'asinın Memâlik-i Mahrûse-i şâhânem mahsûlünden bi'l-mübâya'a diyâr-ı Efrenciye'ye götürecekleri emti'a ve eşyânin iskelelere hîn-i tenzîlinde tecdîd kllınan ta'rîfelerine tatbîkan yüzde dokuz âmediye ve sefinnelere tahmîlinde yüzde üç reftiye gümrükleri alınmakda ve Memâlik-i Mahrûsem'den mübâya'a ile yine Memâlik-i Mahrûsem derûnunda fürûht edecekleri emti 'a ve eşyânın resm-i gümrük ve masdariyesi dahi re âyâ-yı Devlet-i Aliyyem misillü alınup teb'a-i Devlet-i Aliyyem olan berâtlu Avrupa tüccârı haklarında dahi bu usûl icrâ kılınmakda olduğuna ve bu makûle Memâlik-i Mahrûsem mahsûlü olan eşyâyl celb eden ehl-i İslâm tüccârından yüzde dört ve re 'âyâ-yı Devlet-i Aliyyem tüccârından gayr-i ez-masdariye yüzde beş resm-i gümrük ve resm-i ihtisâb ve ba 'zı emti 'adan dahi resm-i bid'at ve ruhsatiye ve mürûriye misillü bir takım rüsûmât-ı mütenevvi 'a ahz ve tahsîl olunarak [...]" (KŞS.,38/128-1) şeklinde idi.

Emrin devamında bu tarife çerçevesinde yürütülen vergilendirmenin Tanzimat'ın ruhuna aykırı olduğu vurgulanarak, yeni düzenlemeye ihtiyaç duyulduğu belirtilmekteydi. Bu meyanda mesele Maliye Nazırı İbrahim Saib Paşa tarafindan Meclis-i Vâlâ-yı Ahkâm-ı Adliye’ye havale edilmiş ve burada müzakereye açılmıştı. Müzakere edilen meseleler Kıbrıs’taki görevlilere de bildirilmişti. 
Bu husus, “[...]hâlbuki zikr olunan Tanzîmat-ı Hayriye'nin te'sîs ve icrâsından maksad-ı aslî-i şâhânem vergü-yi memâlikde ve rüsûmât-ı mukarrere-i sâ'irede usûl-i i'tidâl ve hakkâniyyetin ifâssyla bi'l-cümle ahâlî ve teb 'anin sâye-i merâhim-vâye-i mülûkânemde bi'l-vücûh himâyet ve styânetleri kaziyye-i hayriyesinden ibâret bulunduğuna binâ'en mahsûs-ı zât-ı hümâyûnum olan şîme-i kerîme-i ra'iyyet-perverî ve ma'delet îcâbınca düvel-i müşârun-ileyhim teb'asının mu'âhede-i cedîde-i merkûmeden dolayı nâ'il oldukları imtiyâz ve müsâ'adât ba'd-ezîn teb 'a-i Devlet-i Aliyyem'den olan berâtlu ve berâtslz bi'l-cümle ehl-i İslâm ve re âyâ tüccârt vesâ'ir hakkinda dahi bî-dirîğ erzân kulınarak kâffe-i teb'a ve tüccâr-ı Saltanat-ı Seniyyem'in dahi Memâlik-i Mahrûsem mahsûlünden mübâya'a ve celb edecekleri emti'a ve eşyâ ve zehâyir ve erzâkdan mahallinde bâyi 'i tarafindan verilecek öşründen mâ 'adâ düvel-i müşârun-ileyhim teb 'a ve tüccârı haklarında tanzîm olunan ta 'rifeler vechile iskelelere hîn-i tenzîlinde ale'l-umûm yüzde dokuz âmediye ve taşra götürdüklerinde yüzde üç reftiye resmi alınması zımnında îcâbının icrâsı husûsu hâlâ umûr-ı mâliye nâzırı düstûr-ı mükerrem müşı̂r-i mufahham nizâmü'l-âlem müşı̂r-i sadâkat-semîrim el-Hâc İbrahim Saib Paşa edâma'llâhu te 'âlâ iclâlehû tarafindan bâ-takrîr ifâde ve inbâ olunmuş ve keyfiyyet Meclis-i Vâlâ-yı Ahkâm-ı Adliyem'de dahi bi'l-müzâkere[...]" (KŞS.,38/128-1) şeklinde beyan edilmişti.

Osmanlı devleti yerli tüccarını imtiyazlı yabancı tüccarlara karşı korumaya çalışıyordu. Ancak bu girişimi tüm yerli ve yabancı tüccarlar arasında eşitlik sağlanması zaruretine dayanıyordu. Hükümet böylece tebaasının haklarını da koruyacağına inanmaktaydı. İngiltere ve Fransa devletlerinin tüccarlarına verilmiş haklar üzerinden yerli tüccarın durumunun eşitlenmesi amacıyla yürütülmekte olan çalışmalara, bu emirle birlikte Rusya da dâhil edilmekteydi. Ancak Rusya hakkındaki gümrük tarifesi bir muahede ile yenilenmediğinden, Rusya tüccarlarından talep edilecek gümrük ve sair vergiler, henüz ticaret anlaşması yapılmamış devletler statüsünde devam edecekti (KŞS.,38/128-1).

Bu durum da, "[...]vâkı' a tüccâr-ı merkûmenin cümleten siyyân tutulması ezher-cihet suhûlet-ı maslahatı ve teb 'a-i Devlet-i Aliyyem haklarında başkaca fầide ve menfa'ati mûcib olacă̆g ve fakat Rusya Devleti'nin tecdîd-i ta 'rifeleri derdest olarak bu vechile devlet-i müşârun-ileyhâ teb 'a ve tüccârrndan ve henüz mu 'âhede-i ticârete dâhil olmayan teb 'a ve tüccâr-l ecnebiyeden alınacak gümrük rüsûmâtında usûl-i sâbıkanın şimdilik kemâ-kân icrâsı lâzım geleceği mütâla'a olunarak vech-i meşrûh üzre tesviyesi tensîb ve istîzân olunmuş ve ol vechile îcâbinın icrâsı husûsuna irâde-i seniyye-i mülûkânem ta 'allukuyla ol bâbda emr-i hümâyûn-ı şevket-makrûn-ı pâdişâhânem şeref-efzâ-yl sünûh u sudûr olarak mûcebince keyfiyyet Memâlik-i Mahrûse-i şâhânemde kâ'in gümrüklere başka başka evâmir-i şerîfem isdâr ve isrâ ve İstanbul gümrüğ̈̈ tarafina ilmuhaberi $i$ 'tâslyla bildirilmiş olmağla vech-i meşrûh üzre amel ve harekete mübâderet olunmak fermânum olmağın [...]" (KŞS.,38/128-1) şeklinde ifade edilmişti.

Buna göre Osmanlı iskelelerine mal indiren bu ülke tüccarlarından \%9 ithalat ve yine iskelelerden mal ihraç eden tüccarlara $\% 3$ olarak uygulanan gümrük vergilerinin Müslim ve gayrimüslim Osmanlı tüccarlarına da sağlanacağı bildirildi. Açıkçası bu durum Osmanlı Devleti'nin ilgili dönemde kendi pazarını yabancılara karşı korumakta içine düştügü zaafı göstermektedir. Çünkü kendi tebaası olan tüccarların ödemek zorunda oldukları vergilerin düzenlenmesinde diğerlerinin karine addedilmesi iktisadi olduğu kadar siyasi ve askeri bir zaafın da göstergesi olarak görülmelidir (KŞS.,38/128-1).

Bu husus da, "[...] işbu emr-i celîlü'l-kadrim ısdâr ve tesyâr olunmuşdur imdi teb 'a-i Saltanat-ı Seniyyem'den olan kâffe-i tüccâr vesâ'irenin Memâlik-i Mahrûsem mahsûlünden celb edecekleri emti'a ve eşyâ ve zehâyir ve erzâkdan el-hâletü hâzihi alınmakda olan rüsûmât-ı mütenevvi 'a-i kadîmeden sarf-ı nazarla ba'd-ezîn bâlâda beyân olunan usûle tatbîkan ya 'ni düvel-i müşârunileyhim tüccârının mu'âhede-i merkûmeden dolayı mazhar oldukları müsâ'ade ve imtiyâza tevfikan mahallinde bâyi 'i tarafindan verilecek össründen mâ' 'adâ müsâvâten yüzde dokuz âmediye ve yüzde ü̧ reftiye olmak üzre resm-i gümrük alınması ve diyâr-l ecnebiyeden getürecekleri emti 'a ve eşyâdan dahi düvel-i müşârun-ileyhim ile tanzîm olunan ta 'rife-i cedîde mûcebince kadîm olan yüzde üç resm-i gümrük ve rüsûmât-l sâ' 'ire yerine yüzde iki resm-i munzamm ki cem 'an yüzde beş gümrük ahz ve tahsîl kllinması ve Rusya Devleti teb'a ve tüccârıyla mu'âhede-i ticârete dâhil 
olmayan sâ 'ir tüccâr-ı ecnebiyenin Memâlik-i Mahrûsem'den bi'l-mübâya 'a götürdükleri emti 'a ve eşyâ ve erzâk vesâ'irenin gümrük ve bi'l-cümle rüsûmâtı bâyi 'inden ve memâlik-i ecnebiyeden getürdikleri emti 'a ve eşyâ vesâ'irenin dahi yüz üç hesâblyla resm-i gümrügü̈ kendülerinden ve rüsûmât-ı sâ 'iresi müşsterîsinden alınmak üzre bunların haklarında usûl-i sâblkanın icrâ olunması irâde-i seniyye-i mülûkânem muktezâsından ve taşralardan Dersa 'âdetüm'e tevârü̈d edecek emti 'a ve eşyâdan taşra gümrüklerinde resm-i gümrük mutâlebe ve ahz olunmayup fakat Dersa âdetüm'e vusûlünü hâvî İstanbul gümrügünden ilmuhaber getürmek üzre eşyâ-yı merkûme ashâbr taşra gümrüklerinde küfelâya rabt olunarak iktizâ eden gümrükleri Dersa âdetüm gümrüğünde alınması bâ-hatt-ı hümâyûn mü'esses olan gümrük nizâmı iktizâsından idüği[...]” (KȘS.,38/128-1) şeklinde belirtilmişti.

Kıbrıs ekonomisi, XIX. yüzyılda zirai üretime dayanıyordu. Ticaret de Kıbrıs'ın tarıma dayalı iktisadi hayatında önemli bir rol oynamıştı. Osmanlı idaresi esnasında Kıbrıs'ta ihracat her zaman ithalattan hacim ve kıymetçe daha yüksek olmuştur ${ }^{18}$. Bunun sebebi adanın nüfus olarak az, toprak olarak verimli olması idi (Ayar, 2012, s. 350). İhracat da zirai mahsullerin satılmasına dayanıyordu. Tuzla kasabası, Türk fethinden sonra Kıbrıs'ı dış dünyaya bağlayan önemli bir ticaret merkezi olarak gelişmişti. Bu sebeple devletler burada konsolosluklar kurmuşlardı. XIX. yüzyıl ortalarında Tuzla limanına yılda ortalama 150 kadar Avrupa gemisi geliyordu. İthalat ve ihracat bu gemilerle yapılıyordu. Kasabada yarısı Avrupalı olmak üzere 50 kadar tüccar faaliyet gösterirken (Ayar, 2012, s. 348)bu tüccarlar içerisinde Ruslar da vardı.

Rusya konsolosları, 1840'lı y1llarda siyasi faaliyetlerden uzak durdular. Bunda Misir meselesinin İngiltere vasıtasıyla çözülmesinin etkisi vardı. Rus konsoloslar siyasi alandan çekilince faaliyetlerini ticaret üzerinde yoğunlaştırdılar. Bu yıllarda bazı Ruslar uzun yıllardır süregelen ticarî faaliyetlerinin bir sonucu olarak, Osmanlı tebaasından kişilerle aralarında güven tesis etmişlerdi. Bu güven onların Kıbrıslılardan veresiye mal alabildikleri bir ortam meydana getirmişti. $\mathrm{Bu}$ suretle yerel halka borçlanıyorlardı.

$\mathrm{Bu}$ borca dair bilgiler, "Medîne-i Lefkoşa'da Ayasofya Mahallesi sükkânından olup Mekke-i mükerreme-i şerrefehallâh'da ikâmet üzre iken bundan akdem fevt olan Bekir Ağa bin el-Hâc İbrahim Ağa nâm müteveffânın verâseti: Der zimmet-i Rusyalu Papas oğlu Yorgi bâ-temessük 216 guruş(KŞS., 41/77-1); Cezîre-i Kıbrıs'da kâin Girinye kazâsına tâbi" Ayairini nâm karyede mütemekkin iken bundan akdem helâk olan Mihail veled-i Kostandino nâm zimmînin verâseti: Der-zimmet-i Rusyalı Mihail 180 guruş(KŞS., 41/100, 103-1); Medîne-i Lefkoşa mahallâtından Arab Ahmed Paşa mahallesinde sâkin iken bundan akdem fevt olan el-Hâc Ahmed bin Mustafa'nin verâseti [...];Deyn-i müsbet-i Rusya teb'asından Yanaki Yanarvili an-semen-i çiftlik 24.000 guruş” (KŞS., 42/140-1)olarak belgelere de yansımıştı.

Rusların bu dönemde Kıbrıs'taki ticari faaliyetleri, kendi ekseninde inişli çıkışlı süreçler halinde cereyan etmesine rağmen üçüncü taraf olarak İngiltere de sürekli biçimde bu ticareti gözetim altında tutuyordu. Bunun sebebi Rusyalı tüccarların tabi oldukları gümrük vergisi rejimi idi. 1838 Balta Limanı Ticaret antlaşmasından sonra İngiltere tüccarlarithalatta $\% 2$, ihracatta $\% 9$ munzam resim ödemekteydiler. Osmanlı devleti ile Rusya arasında henüz böyle bir muahede yapılmaması dolayısı ile Rusya'nın tabi olduğu gümrük vergisi rejimi eski ahitnamelere göre sadece \%3 idi. İngilizler, Rusya tüccarlarının ödemesi öngörülen bu oran karşısında, diğer milletler ve bilhassa Rus tüccarı ile rekabet etmelerinin imkânsız olduğunu belirtiyorlardı. İngilizler ihraç mallarında $\% 12$, Ruslar ise \%3 öderlerse İngiltere ile ticaret yapan bütün yabancıların Rus himayesini kabul edeceği, bu suretle de İngiltere ile Türkiye arası ticaretin Rus himayesindeki tüccarın eline geçeceği görüşündeydiler. Bunun ise ancak bütün diğer milletlerin muahedeyi kabul ettikleri takdirde önlenebileceğine inanıyorlardı (Kütükoğlu, 2013, s. 203). Nitekim 1841'de Edirne ipek piyasasındaki durum, ihraç için sadece \%3 ödemeleri dolayısı ile Rusların lehine idi (Kütükoğlu, 2013, s. 204).

18 18. yüzyılın ikinci yarısından itibaren Kıbrıs'tan yapılan ithalat ve adaya yapılan ihracata konu olan mallar hakkında ayrıntılı bilgi Ayar tarafından verilmiş̧ir (Ayar, 2012, s. 350-354). 
29 Muharrem 1257/23 Mart 1841 tarihinde Kıbris Muhassılı Mehmed Talat, umur-1 zabita memuru Mustafa Bey ve Lefkoşa naibine yazılan emirde bu husus açıklığa kavuşturuluyordu. İngiltere ve Fransa ile yapılan ticaret antlaşması şartları bütün Müslümanve reaya tüccar ile Rusya ve henüz yeni ticaret antlaşmasına dâhil olmayan diğer devletlere de uygulanacaktı. Bu durum tüm taşra gümrüklerine bildirilmişti. Bu emirde, Rusya Devleti tebaa ve tüccarlarının Osmanlı memleketlerinden satın alıp götürdükleri tüm mal, eşya ve erzakın bütün gümrük ve sair vergileri satıcıdan alınacaktı. Kıbrıs'a ithal ettikleri ticari mallar için $\% 3$ gümrük vergisini kendileri, geri kalanını ise müşterileri ödeyecekti.

$\mathrm{Bu}$ durum, "[...] Rusya Devleti teb'a ve tüccârtyla sâlifü'z-zikr mu'âhede-i ticârete dâhil olmayan sâ'ir tüccâr-ı ecnebiyenin Memâlik-i Mahrûse-i Şâhânem mahsûlünden bi'l-mübâya'a götürdükleri emti'a ve eşyâ ve erzâk ve sâ'irenin gümrük ve bi'l-cümle rüsûmâtı bâyi 'inden ve memâlik-i ecnebiyeden getirdükleri emti 'a ve eşyâ ve sâ'irenin dahi yüzde üç hesâbiyla resm-i gümrü̈̆̈̈ kendilerinden ve rüsûmât-ı sâ'iresi müssterîsinden alınmak üzre bunlar hakkinda usûl-i sâbıkanın şimdilik muvakkaten icrâ olunması münderic ve musarrah bulunmuş olup [...]” (KŞS., 39/17-1) şeklinde açıkça ifade edilmişti.

Bu dönemdeki ticari faaliyetleri düzenleyen yeni Osmanlı Rus gümrük tarifesi, 27 Ekim 1842 tarihinde imzalandı. Tarife İngiltere tarafını tatmin etmemiş ve yeni iddialar ortaya atmalarına yol açmıştı; çekinceleri vardı. Gümrük tarifesinin imzalanması, İngiliz Elçisi Canning'in Osmanlı Hariciye Nazırı Sârım Paşa'dan aldığı garantiler üzerine kurulmuştu. Buna göre Rus gümrük tarifesi, İngiliz, Fransız ve Avusturya tarifelerinin benzeri olacak ve tarife 12 yıl süreyle yürürlükte kalacaktı. Tarifede ithalat ve ihracat için tespit edilen resim sadece \%3 idi. Ayrıca Kütükoğlu, bu çekincelerin haklı olmadığını beyan etmiştir (Kütükoğlu, 2013, s. 205).

\section{Rusya Tüccarlarına Sehven Sağlanan Avantajlar}

Osmanlı Devleti'nin Rusya ile olan siyasi ilişkilerini tanımlayacak en etkili kavram şüphesiz değişkenlik yahut kırılganlık olabilirdi. Ancak bu kırılganlık hali içerisinde yine de Osmanlı bürokrasi çevrelerinin kendilerine mahsus bir strateji dâhilinde hareket ettikleri düşünülmektedir. Çünkü 1838 Balta Limanı antlaşması ile ortaya çıkan yeni ticaret rejimi İngiltere, Rusya ve Osmanlı devletleri üçgeninde bir istikrar ve ticari barış rejimi yaratmaktan çok uzaktı. Yukarıda da üzerinde durulduğu gibi İngiltere bu rejimden kendi tüccarlarının aleyhine olması hasebiyle ciddi derecede rahatsızlık duymaktaydı. Bu rahatsızlıklarını büyükelçilikleri düzeyinde Osmanlı makamları üzerinde baskı kurmak suretiyle de açığa çıkarmaktaydılar. Osmanlı maliye ve siyasi bürokrasisi, İngiltere'nin bu anlaşma ile elde ettiği yıkıcı etkiyi, onun rakibi büyük güç Rusya ile el altından ittifak kurarak dengeleyebilirdi. $\mathrm{Bu}$ da ancak Rusya tüccarlarının Osmanlı ülkesindeki faaliyetlerinde kendilerine İngiltere'ye nazaran avantaj sağlayan vergilendirme sistemi ile mümkün olabilirdi. Sicil metnine de yansıyan "sehv-i kalem" ifadesi hakikaten gerçeği yansıtmıyorsa, bunun izahı ancak bu şekilde yapılabilirdi; Osmanlıların İngiltere'nin Osmanlı ülkesindeki ticari tekelini kırmak üzere Rusya'y1 kendi eliyle güçlendirdiği bir mekanizma planlanıp uygulanmış olmalıydı. Aksi halde bu ancak büyük bir skandal olabilirdi. Osmanlı bürokrasisi yıllarca süren vergi rejimini, ancak bir şikâyete konu olunca kurnazca kalem hatasına bağlayarak kendini temize çekmiş oluyordu.

Aradan 10 y1l geçtikten sonra Osmanlı idarecileri, tüm taşra gümrüklerine gönderdikleri emirde, Rusya tüccarlarının gümrük vergilendirmeleri hususundaki düzenlemenin kaynağı olan metinde yazım yanlışı yapıldığını anladılar. İfadenin; Osmanlı memleketlerinden ihraç edilen mahsulün reftiye gümrüğünün gümrük çıkışında tüccardan, sair vergilerin de satıcıdan alınması şeklinde yazılması gerektiğini fark ettiler. 
Bu durum, "[...]Hâlbuki Memâlik-i Mahrûse-i Şâhânem mahsûlünden alup götürdükleri eşyânın reftiye gümrüğ̈̈ kendülerinden ve sâ'ir bi'l-cümle rüsûmâtı bâyi 'inden alınması denilecek iken sehv-i kalem olarak gümrük ve bi'l-cümle rüsûmâtı bâyi 'inden alınmak üzre deyü derc ve tahrîr olunmuş [...]” (KŞS., 39/17-1) şeklinde beyan edilmişti.

Rusya tüccarlarının bu çerçevede uzun müddet ticaret yaptıkları açıktır. Buna rağmen böyle bir uygulamanın ahali ve fukaraya gadre yol açacağı belliydi. Yani Rusya tüccarlarının Osmanlı memleketinden alıp götürdükleri ticari mallardan ödemeleri gereken $\% 3$ gümrük vergisi de taşra gümrüklerinde satıcı olan yerli ahaliye yüklenmiş olacaktı. Tabii ki Rusya tüccarı gümrük maliyeti olmaksızın, ticaret yapacaktı. Bu durum Vâridât Muhâsebesi veDivân-1 Hümâyun Kaleminde mevcut kayıtlar tashih edilerek yeniden düzenlendi. Bundan böyle, diğerleri de dahil olmak üzere Rusya tebaa ve tüccarları hakkında bu usulün muvakkaten tatbik edilerek, Osmanlı memleketlerinden ihraç edecekleri malların reftiye gümrüğünü kendileri, diğer vergileri de satıcıların ödemesi gerektiği, Kıbrıs yetkili makamlarına bildirildi (KŞS., 39/17-1).

Buna dair hüküm, "[...] Keyfiyyet ahâlî ve fukarâya gadri mûcib ya'ni tüccâr-ı merkûmenin Memâlik-i Mahrûsem mahsûlünden mübâya'a ederek diyârlarına götürdükleri eşyâ içün kendülerinden ahzı lâzım gelecek yüzde ü̧̧ guruş resm-i gümrük dahi taşra gümrüklerinde bâyi ' $i$ olan fukarâya tahmîl olunduğu hâlde bi'l-vücûh hasârı müstevcib olacağı ve tüccâr-ı merkûme dahi Memâlik-i Mahrûsem mahsûlünden mübâya'a edecekleri eşyâyı bilâ-resm meccânen diyârlarına götüreceklerinden [...]” (KŞS., 39/17-1) şeklinde kaydedilmişti.

\section{Rusya Tüccarlarının Gümrük Rejiminden Kaynaklanan Bir Asayiş ve Mali Mesele: İpek (Harir) Kaçakçılığı}

Rusya'nın Kıbrıs'taki ticari faaliyetleri, 1842 yılında, eskiden beri süre gelen ahidnâmeler hükmüne göre yenilenmişti (Kütükoğlu, 2013, s.213). Bu rejim 9 Mart 1845 tarihinde tekrar düzenlemeye tabi tutuldu. Kıbrıs'taki idarecilere adadaki ihtisâb rüsumu (Demiryürek, 2012, s. 553605) ve sair gümrük mukataalarının ihalesi vesilesiyle gönderilen bir ferman, burada tatbik edilen gümrük tarifelerini yeniden düzenledi. Ferman ayrıca Rusya tüccarlarının adadaki ticari işlemlerinde tabi oldukları vergi nizamını da belirlemekteydi.

Osmanlı Devleti ve Rusya arasında Osmanlı ülkesinde bu devletlerin tüccarlarının yürütmekte oldukları ticarette gümrük rejimi tartışmaları sürerken, İngiltere tarafı bir konuyu kendi içinde

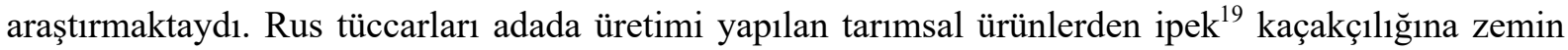
hazırlamaktaydılar. İngiltere taşradaki tüccarlarından, bu kaçakçılığın kendi tüccarı ile Rusya tüccarı arasındaki rekabette, kendileri açısından bir dezavantajı olup olmadığını öğrenmek istiyordu. İngiliz tüccarlar kendi ticaretlerini dürüst ticaret olarak nitelendiriyorlardı (Kütükoğlu, 2013, s. 206). İngiltere'nin iddiasına göre; Rus tüccarlar, mahsulü yerinde satın alarak veya üreticiyle anlaşma yapıp kaçak olarak sahile getirmesini temin ederek daha ucuza mal etme imkânına sahip olacaktı. Çünkü üretici \%9 resimden kurtulacağı için, maliyet ucuzlayacak; Rus tüccarı böylece rakiplerinden avantajlı hale gelecekti (Kütükoğlu, 2013, s. 208).

1845 tarihli fermanda, aynı zamanda açıkça belirtmemiş olmasına rağmen, Rusya, Kıbrıs’ta ipek ticareti yapmaktaydı. Rusya tüccarlarının ipek ticareti çerçevesinde kaçakçılık faaliyetlerine de zemin oluşturucu bir tutum içinde olduğu fermanın ifadelerinden zımnen anlaşılmaktadır. Zira ferman, açıkça

\footnotetext{
19 Kıbrıs'taki ipek üretimi hakkında ilk bilgiler, 8 Şubat-28 Mart1508 tarihlerinde Kıbrıs'1 ziyaret eden Martin Von Baumgarten'den nakledilmektedir. Baumgarten, Baf'a yaptığı ziyaret esnasında, bu bölgede Scandilora köyünde, gemiye misır ve ipek yüklenene kadar beklediklerini ifade eder (Cobham, 1908,s.55).
} 
ipek kaçakçılığına firsat verilmemesini de emretmekteydi. Rusya'nın satın aldığı ipeğin gümrük vergisi de $\% 12$ olarak tespit edilmişti ${ }^{20}$.

İpek, vergi itibariyle aşara tabi idi. Bu dönemde gümrük gelirleriyle birlikte iltizama verilerek vergilendirilmekteydi. Ancak zaman zaman alıcı tüccarlar ipeği doğrudan üretici ile temas kurarak satın almakta, ipek mizan yani tartı mahalline götürülmeksizin kaçırılmaktaydı. $\mathrm{Bu}$ sebeple mültezimler zarar etmekteydi. Bu tarihte, ipek kaçakçılığının önlenmesi amacıyla tedbirler alındı. İlk tedbirler cezalandırmaya yönelik bir tür tehdit mahiyetinde idi. Buna göre, ipek kaçakçılığı yapan kişiler yakalanmaları halinde ellerindeki ipeğe el konulacak, kaçakçıların elindeki ipeğin alınmasıyla yetinilmeyip tutuklanacaklar, isim ve şöhretleriyle kayıt altına alınıp Ceza Kanununa göre yargılanmak üzere İstanbul'a gönderileceklerdi. Kaçakçılığın önüne geçilebilmesi için yapısal tedbirler de alındı. İpek, kime ait ise mancınıkta iken tespit edilecek, mültezim tarafindan gümrük vergisi alındığına dair mühürlü ve imzalı bir tezkire tanzim edilerek sahibine verilecekti. Bu tezkire olmaksızın kimsenin gümrüklerden ipek geçirmesine müsaade edilmeyecekti (KŞS., 40/30-1).

Osmanlı Hükümeti, bu tarihte ipek kaçakçılığını önleyici tedbirler alırken, Rusya tüccarının Bursa Harir Gümrüğü hakkında cari olan usule göre satın aldığı ipeğin res-i gümrügünden başka tarife-i cedide $\% 12$ hesabıyla resm-i gümrüğünde gereken noksanı satanın elinden alınacaktı (KŞS., 40/30-1).

Öte yandan Rusya'nın Osmanlı ülkesinden ihraç edeceği ipek hususunda tatbik edilen usul ve esas bu ferman metninde ayrıntılarıyla verilmesine rağmen, nihai rejim 1846 muahedesi ile tespit edilecekti. 1846 Rusya Ticaret Muahedesi ile Osmanlı Devleti, Rusya tüccarlarının esnaflık yapmalarını yasaklayarak, bunların perakende ticarete girmelerini önlemek istemişti (Kütükoğlu, 2013, s. 228-229). Rus tüccarı ihraç edeceği ipeği istediği limandan gemiye yükleme hakkına sahip değildi. Hangi bölgenin ipeklerinin hangi limanlardan ihraç olunacağına dair defter sefarete verilmiş olup Osmanlı Hükûmeti sefarete haber vermeksizin bunda değişiklik yapmayacaktı (Kütükoğlu, 2013, s. 227).

$\mathrm{Bu}$ durum, "[...] Rüsûmât-ı mezbûre ta 'rifeler vechile ahz ve tahsîl olunmak ve harîr a şấr husûle gelen mahallerden harîr mîzân mahalline getirilmeyerek kaçırllup ahz ve girift olduğu hâlde her kimin mâlı olur ise olsun cânib-i mîrîden zabt kllınmak ve bir kerre tutulup da tekrâr harîr kaçırmağa mütecâsir olanların yalnız yedlerinde bulunan harîrin zabtıyla iktifâ olunmayup bu makûle harîr kaçıran şahıs her kim olur ise olsun Dersa 'âdetüm'e celb ile ber-mûceb-i kânûn-ı cezâa te'dîbât-ı lâyıkası icrâ olunmak içün derhâl keyfiyyeti isim ve şöhretiyle der-bâr-l şevket-karâruma bâ-i'lâm inhâ olunmak ve harîr mahsûlü mancınıkda iken ashâbının isim ve şöhretiyle mahallerinde sebt ve tahrîr olunarak iktizâ eden gümrüğ̈̈ te'diye olunduğunu mübeyyin mülteziminin memhûr ve ma 'mûlün-bih tezkiresi olmadlkça bilâ-tezkire harîr mürûr etmemesine mahalleri me'mûrları taraflarından kemâliyle i 'tinâ ve dikkat kllınmak [...]”' (KŞS., 40/30-1) şeklinde ifade edilmişti.

Rusya tüccarlarının Kıbrıs’ta yürütmekte oldukları ipek ticareti, Bursa Harir Gümrüğü şartlarına göre yürütülmekteydi (Kütükoğlu, 2013, s. 213). Bu durumda ipek ticaretinin vergilendirilmesi hususu, mevcut uygulamadaki bazı sorunlara da işaret etmekteydi. Kabaca bir değerlendirmeyle, Rus tüccarlar, Kıbrıs’tan alıp ihraç ettikleri diğer ticari mallar gibi ipek ihracında da neredeyse gümrük vergisi ödemiyorlardı. Bu durum, Osmanlı idarecileri tarafından normal karşılanırken İngiltere'nin uzun yıllardır şikâyetlerine konu olmaktaydı (Kütükoğlu, 2013, s. 202-218). İngiltere tüccarları, 1838 Balta Limanı Antlaşmasından itibaren, öngörülen gümrük vergilerini \%12 olarak verirken, Rus tüccarlar, henüz Osmanlı ve Rusya Devleti arasında ticaret ahidnamesi yapılmaması sebebiyle önceki tarife üzerinden \%3'lük bir vergi veriyorlardı. Bu statü 1845 yılında da aynı şekilde devam etmekteydi (KŞS., 40/156-1).

\footnotetext{
${ }^{20}$ Kıbrıs Emti‘a Gümrüğü ve İhtisâb Rüsûmu ile harîr a'şârı mukataası Hasan Tahsin Bey’e verildiğine dair ferman, Kıbrıs Kâ’immakâmı el-Hâc Mesrur ve kazâların nâ'ib’i ile vücûh-1 cezîreye bildirildi(KŞS., 40/30-1).
} 
Mevcut durum, "[...]Rusyalunun mübâya'a eylediği harîrin müşterîsi cânibinden îfâ olunacak resm-i gümrü̈ünden başka ta 'rife-i cedîdede muharrer yüzde on iki hesâblyla îcâb eden resm-i gümrügüne terettüb eden noksânı bâyi 'i yedinde kalacak olduğundan o makûleler bâyi ‘ $i$ bulunandan ahz ve îfâ kllinmak ve gümrüklerin dahi karâr-gîr olan şürût ve nizâm ve lâyiha ve ta 'rifesine tevfikan zabt ve idâre olunmak mü'esses olan şürût ve nizâmı iktizâsından olduğuna binâ'en [...]”" (KŞS., 40/30-1) şeklinde belgelere yansımışt1.

Nitekim 1846 yılında Rusya ile ticaret muahedesi yapılarak yeni rejim tespit edilebildi. Rus muahedesiyle bundan evvel 10 Haziran 1783 Ticaret Muahedesi ve Edirne Muahedesinin 7. maddesinde tespit edilmiş olan ve bu defa değişikliğe uğramayan esasların yürürlükte olduğu kabul edilmişti. Buna göre genel çerçevede olmak üzere, ihracat ve ithalatta alınacak resimler diğer milletler tüccarının ödemekte olduklarına eşit kılınmış, yani Rus tüccarının da ithalatta $\% 2$, ihracatta \%9 munzam resim ödemesi şartı konulmuştur. Buna karş11ı Rus tüccarı da ihracat veya Osmanlı memleketleri dâhilinde satmak için her türlü eşyayı satın alma ve istedikleri iskeleye nakl ile ihraç etme imtiyazını elde etmişti (Kütükoğlu, 2013, 226).

\section{Kıbrıs Halkı ve Ruslar Arasındaki Alacak Verecek İlişkileri}

Rusya tebaası şahıslar, Kıbrıs ahalisinden Müslüman ve gayrimüslim şahıslarla iş veya alacak verecek ilişkileri tesis etmişlerdi. Rus tüccar ve konsolosları Tuzla'da ikamet etmelerine rağmen, borçlandıkları Osmanlı Devleti vatandaşları Ada'nın muhtelif bölgelerindendi. Hatta Tuzla’ya oldukça uzak mesafede olan köylerde bile bağlantıları vardı.

Rusların, Kıbrıs'ta Osmanlı tebaası kişilerle aralarında borç ve alacak ilişkisinin olduğuna dair bazı örnekler tereke kayıtlarında da mevcuttur. Alacak verecek ilişkilerinde rakamlar bazen küçük boyutlarda olmasına rağmen kimi zaman oldukça yüksek sayılabilecek meblağ da söz konusuydu.Bununla ilgili bazı örneklere bakılırsa, Lefkoşa Ayasofya Mahallesi sakinlerinden olup Mekke'de vefat eden Bekir Ağa bin el-Hâc İbrahim Ağa'nın, Rusyalu Papas oğlu Yorgi'den 216 kuruş alacağı vardı(KŞS., 41/77-1). Girinye kazasına bağlı Ayairini köyünden Mihail veled-i Kostandino'nun Rusyalı Mihail'den 180 kuruş alacaklı olduğu yazılıydı (KŞS., 41/100, 103-1).

Zikredilen bu rakamlarla kıyaslanınca, dönemin iktisadi şartları da gözetilerek, büyük meblağların da alacak verecek kayıtlarına yansıdığı görülmektedir. Buradaki örnekte bir çiftlik hissesinden bahsedilmektedir. Ancak borcun ne sebeple oluştuğu belirtilmediğinden, Rusya teb'ası olan şahsın Müslüman ahaliden gayrimenkul satın aldığı veya birlikte çiftlik işlettikleri düşünülebilir.Bu çerçevede Lefkoşa Arab Ahmed Paşa Mahallesi sâkinlerinden el-Hâc Ahmed bin Mustafa'nın Rusya teb 'asından Yanaki Yanarvili'den çiftlik hissesi olarak senetli 24.000 kuruş alacağ vardı (KŞS., 42/140-1).

Rusya tüccar ve konsoloslarının Ada'daki faaliyetleri, sık sı kesintiye uğramasından olsa gerek, Rus tebaası şahısların Osmanlı toplumuyla temasları, diğerlerine göre sınırlı idi. Nitekim 18311832 yılında Kıbrıs'ta yapılan nüfus, emlâk ve arazi sayımlarında konsolosların mal varlıkları da kayıt altına alınmıştı. İşte bu şekilde meydana gelen Temettuat defterlerinden Rus konsolosu ve diğer Rus tebaası şahısların mülkiyet durumunu tespit etmek mümkündür. Rusya konsolosu Peristiyani bu dönemde Ada'dan çıkartılmış olduğundan yerine Felemenk konsolosu işlerini yürütüyordu. Peristiyani'nin Tuzla İskelesindeki evi kendi mülkiyetindeydi ve 15.000 kuruş tutarındaydı (BOA., ML.VRD.TMT.d., 16153, s. 168). Sava veled-i Nikola ve Mavdeli Aci Mavcili zevcesi İskelede kendi evlerinde ikamet ediyordu (BOA., ML.VRD.TMT.d., 16153, s. 169) ${ }^{21}$.

\footnotetext{
${ }^{21}$ Sava veled-i Nikola'nın evi iki katlı olup 4 oda ve 1.000 kuruş; Aci Vancili zevcesinin evi 8 odalı ve 2.500 kuruş kıymetindeydi.
} 


\section{Kıbrıs Emti‘a Gümrüğü, İhtisab Rüsûmu ve İpek İltizamından Kaynaklanan Meseleler}

29 Safer 1261/9 Mart 1845 tarihinde Hasan Tahsin Bey’e Kıbrıs Emtia Gümrüğü, İhtisab Rüsumu ve Harir Aşarı iltizamı verildi. İltizam bedeli başlangıçta 5 yük 92.750 kuruş iken, 1 yük 37.250 kuruş zam yapılarak toplam 7 yük 30.000 kuruşa çıkmıştı. Kıbrıs’taki mahalli idarecilere gönderilen ferman, Tanzimat'a dâhil edilen eyaletlerde tatbik edilecek gümrük tarifelerini ve iltizam düzenlemelerini içeriyordu. Düzenleme 1845 yılı Mart ayı başından gelecek yılın Şubat ayı sonuna kadarki dönemi kapsıyordu. 29 Muharrem 1262/27 Ocak 1846 tarihli ferman bu nizamı yineliyordu (KȘS., 40-30-1). Bu nizama göre ihtisab rüsumunun tahsili şöyle düzenlenmişti (KŞS., 40-156-1):

1. Tanzimat'a dâhil edilen mahallerde ihtisab nizamı işletilecek.

2. İhtisab nizamına göre İstanbul ve sahil gümrügü ile kadim kara gümrüklerine gidecek olan eşya ve emtia kefalete bağlanarak geçiş ruhsatı verilecek.

3. Gümrük bulunmayan mahallerden tezkiresiz gelip veya kazada üretilip sarf edilen ve gümrük olmayan mahallere giden emtia, eşya ve zahirenin ihtisab rüsumu, dekakin yevmiyesi eskiden olduğu gibi alınacak.

4. Mültezimler tarife dışı işlem yapmayacak.

5. Mültezimlerin çalışmalarını mahallinde bulunan müşir, vali, mutasarrıf, defterdar ve kaymakamlar denetleyecek.

6. Sene sonunda meydana gelen temettü 1 akçesi gizlenmeden deftere kaydedilecek.

7. Sene sonunda istemesi halinde mukataa önceki bedele bir miktar zam yapılarak aynı şahsa verilecek. İstemezse bir başkasına ihale edilecek.

8. Mültezimlerin ihtisab rüsumundan zarar etmelerini önleyici tedbirler alınacak.

9. Zarar beyan eden mültezimlerin şikâyetleri dikkate alınmayacak.

10. Mültezimlerin tarife dışında iş yapıp zarar etmeleri halinde "sızıldı"ları dikkate alınmayacak.

11. Tarife dışında iş yapan müteahhidler, mesul ve muhatap olacaklardır.

$\mathrm{Bu}$ düzenleyici tedbirler yanında mültezimlerin işlemlerini yürütürken tatbik edecekleri muhasebe ve kayıt sistemi de düzenlenmişti. Buna göre:

1. İltizam bedelleri vaktinde müteahhid tarafından mükemmel bir şekilde Maliye Hazinesi'ne ödenecek.

2. İhtisab rüsumunun tahsili ve kayıt altına alınması için müstakil defter tanzim edilecek.

3. Zaman içerisinde bazı gümrüklerin gelirlerinde gerileme bazılarında da artış söz konusu olduysa bunlar önceki mültezimlerin elinde kalmıştır.

4. Gümrük vergileri tarifeye göre tahsil edilecektir.

Gümrük nizamının yanında Harir aşarı iltizamı da nizama bağlanmıştı. Öncekinden farklı olarak harir aşarının düzenlenmesinde Rusya tarifesi temel alınmıştı. Rusya bu dönemde Bursa Harir Nizamı çerçevesinde ticaret yapmaktaydı. Düzenleme şöyleydi:

1. Rusya tüccarları satın aldıkları haririn resm-i gümrüğ̈̈nden başka tarife-i cedide $\% 12$ hesab1 üzerinden; \%3'ü alıc1, \%9'u satıcısı tarafindan ödenecekti.

2. Rus tüccarlara gümrükte bu tarife uygulanacak.

3. Gümrük rejiminin işlemesi için ada ahalisinden muteber ve mütedeyyin memurlar tayin edilecek.

4. Bu memurlar işleri gereği gibi idare edecekler.

5. Gümrük işlemlerinde, yabancı tüccarlara önceden verilmiş ahidname şartları çerçevesinde muamele edilecek. Bunun dişında hiçbir uygulamaya girişilmeyecek.

6. Sene sonunda varidat toplanıp defteri tutulacak.

7. Bu defterler Maliye Hazinesi'ne gönderilecek. 
8. Mültezim, sene sonunda elde edilen hasılattan, masraflarını düşüp geri kalanını devlete verecek.

9. Hasılatta fazlalık olursa yarısı Maliye Hazinesine diğer yarısı mültezimde kalacak.

10. Hasılat şayet masrafları karşılamazsa, hesaplarda açık varsa mültezim "zarar, ziyan iddia ve istida"edemeyecek.

Tüm bunlara rağmen devlet Kıbrıs’ta tatbik edilecek gümrük nizamının işlemeyeceğini de öngörmüş biçimde tedbirler almıştı. Bu tedbirler açıkça tarifenin istismar yollarını kapatıcı mahiyettedir. Şöyle ki:

1. Mültezimler daha fazla gümrük vergisi almak için tarifede öngörülenden düşük miktarda vergi talep ederek tüccarı tamah ettirmeyecekler.

2. Tüccarlar diğer bölgelere emtia ve eşya nakletmek üzere "saptırllmayacak".

3. Başka gümrüklerin hasılatına zarar verici işlerden kaçınılacak.

4. Harir kaçakçılığı bu meyanda takip edilip önlenecek.

Yukarıda sadeleştirilerek verilen nizam gümrük, ihtisâb rüsumu ve harir öşrü iltizamlarını, mültezimlerin yapacakları işlemleri kendi içinde tanzim ediyordu. Ancak Rusya konsolosları bu nizama rağmen sisteme sızacak yollar buldular. Sistemin aktörleri üzerinden gerçekleşen bu durum, Rusya konsolosunun tercümanı vefat ettiğinde ortaya çıtı. Konsolos ve Kıbrıs idarecileri arasında bir süre tartışma konusu olup İstanbul'a da yansıyan husus, tercümanlık statü ve imtiyazları hakkındaydı. Ancak tercümanın sandığında çok sayıda iltizam evrakının çıkmış olması meseleyi tarafımızca düşünülen boyuta taşımıştı. Rusya konsolosu ve adamları, adada ekonomik ve mali işlere de müdahil olmuşlard.

Burada ayrıntılarıyla verilmeye çalış1lan anlaşmazlıklarda Rusya konsolosu ve Kıbrıs mutasarrıfının ifadeleri yalın haliyle mültezimi ithama yönelikti. Ancak konsolosun da masumiyetine vurgu yapılmaktaydı. Buna rağmen 5 yıl sonra ortaya çıkan bir durum, meselenin yeniden düşünülmesini zaruri kılmaktaydı. 27 Muharrem 1267/2 Aralık 1850 tarihli şukka, Rusya konsolosunun bu konudaki girişimlerinden birini açıkça ortaya koymaktadır (BOA., HR.MKT., 37/80). Osmanlı tebaasından Lefkoşalı Nikolaki Lefteradi'nin vefatı üzerinde Rusya'nın Kıbrıs konsolosu tarafindan kendi tercümanı olduğu gerekçesiyle eşya ve sandığı içindeki evrakı ile birlikte mühürlenmiş, Osmanlı makamları ise konsolosun buna yetkisi olmadığı gerekçesiyle mührü açmıştı. Lefteradi'nin sandığından çıkan evraktan üzerinde hayli iltizâm olduğu anlaşılmaktaydı. Rusya konsolosluğu bu süre zarfinda Müslüman mültezimleri yeterince gözden düşürerek gayrimüslim Osmanlı tebasının bu işe girmesine katkı yapmış olmalıdır. Lefteradi, Rusya konsolosunun da desteğiyle iltizâm işlerine girmiş olmalıydı.

Burada cereyan eden husus, "Kıbrıs Ceziresi Muhassılının iki kıta şukkası mealinde cezire-i merkumede Lefkoşa mütemekkinlerinden ve tebaa-i devlet-i aliyyeden vefat iden Nikolaki Leftorodi nâm bâzargânın eşyâsı olduğundan hânesinde bulunan sandık ve tolab ve evrâk-ı sâiresi tahrir olunmak üzere iken müteveffa-yl merkûm kendüsünün tercümânı ve Rusya tebaasindan Zaharaki'nin adamı olduğu beyaniyle birlikte tahrir itmesini Rusya konsolosu vekili iddia itmiş olmasiyle ol vechile kendüsine dahi tahrir itdirilmiş ise de müteveffanın muahharan Dersaadet'den gelen bazı evrakı Meclisce muayene olunmaksızın Konsolos-ı mumâileyh ahz ve zabt itmiş ve hâlbuki müteveffanın eşyâsı ve tüccar-l sâire ile dahi ahz ve itası bulunduğundan başka uhdesinde hayli iltizâmat oldı̆ğndan ve hatta Avusturya Devleti tebaasindan birinin dahi 8.000 kuruş alacağı olmasiyle evrâk-ı memhûre kendüsi bulunmadıkca açılmamasını Devlet-i müşârileyhâ konsolosı dahi bamüzâkere iltimâs itmiş idügünden müteveffanın bu kadar işlikli (?) işi olduğu hâlde etrafindan tevârüd iden evrâkın Meclisce muayene olunmaksızın zabt olunması şimdiye kadar emsâli mesbûk olmadı̆ğndan eğer müsaade olunur ise bu keyfiyet hem ihtimâm (?) 
hem ashâb-ı hukuka gadri olacağınadan maa'da badezin Düvel-i mütehabbe konsoloslarının tercüman ve simsarlık hıdmetinde bulunan tebaa-i devlet-i aliyye haklarında usûl ittihâz olunarak fena bir şey olacağı beyâniyle icâbının serian emr ü işâar niyâz olunur (BOA., HR.MKT., 37/80).Derkânar: Konsolos tahrire kata hakk olmadiğından mührinin fekk itdirilmesine ve müteveffanın umurına müdâhalesi kabul olunmamasına dair cevab ve müdahaleden feragat itmesi için sefarete müzekkere" (BOA., HR.MKT., 37/80) şeklinde kayda geçirilmişti.

\section{Rusya Konsolosunun Kıbrıs Gümrük Mültezimini Şikâyet Ettirmesi}

Siyasi işlerden uzak duracağını daha önce taahhüt eden Rusya konsolosu Kıbrıs'ta tatbik edilen gümrük iltizamıyla yakından ilgileniyordu. Hatta Kıbrıs muhassılı es-Seyyid İbrahim üzerinde tesir ederek, onun mültezimleri İstanbul'a şikâyet etmesini, kendisinden ise övgüyle bahsedilmesini sağlamıştı. Rusya konsolosunun Kıbrıs muhassılı üzerinde belirgin bir tesir yaratarak Kıbrıs gümrük mültezimi hakkında şikâyetçi olmasının, onun uzun süredir Kıbrıs'tan gümrüksüz ihracat yapması ve yerel idarecilerin buna göz yummalarıyla ilgisi olmalıdır. Bunun yanında devletin iltizam rejiminin sağlıklı işlemesi için aldığı tüm tedbirlere rağmen mültezimler, bir yolunu bulup sistemi kendi lehlerinde olmak üzere istismar edecek formüller bulmaktaydı. Bununla ilgili görülen bir uygulama, mültezimlerin iltizama aldığı işi başkalarına ihale etmeleriydi.

1844 yılında Kıbrıs gümrüklerini Sürre-i Hümâyun emini Hacı Mehmed Ağa iltizamına almış ve ardından kendi tarafından birkaç kişiye ihale ve iltizam etmişti (BOA., A.MKT., 14/67). Onlar da gümrüklerin idaresini ortaklarından ve Mehmed Ağa'nın akrabası Kıbrıs'lı Mehmed Bey'e ihale etmişlerdi. Kıbrıs muhassılı es-Seyyid İbrahim, 13 Receb 1260/29 Temmuz 1844 tarihinde İstanbul'a yazdığı arzında, iltizam işindeki akrabalık ilişkisinin belirleyici olduğunu anlattı. Muhassıl, Kıbrıs gümrükleri ihalesini alan Mehmed Bey'in kişiliği itibariyle uyumsuz ve kötü tabiatlı, hali ve vaktiyle de yolsuz bir adam olduğunu belirtiyordu. O'na göre mültezim gümrük işleri konusunda Rusya konsolosu ve Rus tüccarlarıyla kavga edip her birinin birer suretle gücenmelerine yol açıyordu. Aralarının bulunması ve barıştırılmaları imkânsızdı. Rus konsolosu ise namuslu ve itibarlı biriydi. Bu sıfatla sürekli olarak mültezim hakkında kendilerine mektuplar yazarak tazyik ettiğini ve ne yapılması gerektiğini İstanbul'a soruyordu (BOA., A.MKT., 14/67).

Bu durum, "Kıbrıs Ceziresi Gümrükleri'ni hâlâ Surre-i Hümâyûn Emini atıfetlü Hacı Mehmed Ăga bendeleri der-uhde ve iltizâm iderek tarafindan çent kita' nefer kesâna ihâle ve iltizâm eylemiş ve onlar dahi gümrük-i mezbûrun emr-i idâresini şeriklerinden ve Ağa-yı mumâileyh bendelerinin akrabasından Klbriŝ̂ Mehmed Bey nâmında bir kimesneye ihâle itmiş ise de, Mir-i mumâileyh zâtında imtizâcsı dersdest (?) ve husumeti sebebiyle evza' ve etvârt yolsuz bir adam olduğundan rüsumât-ı gümrük serreştesiyle bu defa'Rusya konsolosu ve tebaa 'sl tüccarlariyle bazı mertebe münâzaa' ve münâkaşa vadilerine kalkışarak her birerlerini birer surette gücendirmiş ve bu sırada da bazılarının ıslâh ve te sifi mümkün olamadı̆̆ı misillü konsolos-i mumâileyh her-bâr eda 'i-yi nâmus suretiyle taraf-ı abidânemi mekâtib-i resm tesyâriyle tazyik eylemekte bulunmuş olmağla[...]" (BOA., A.MKT., 14/67) şeklinde belgeye yansımıştı.

Rusya konsolosunun mevcut gümrük rejimi altında İngiltere tüccarlarına nazaran vergi avantajlı ticaret yapması, belirtildiği gibi İngiltere'yi rahatsız etmekteydi. Rahatsılığın sebebi Rusya tüccarlarının İngiltere tüccarlarına oranla $\% 9$ gibi oldukça yüksek oranda avantaja sahip olmaları idi. Bunun yanında Hill'in anlatımlarında adadaki yerel idarecilerin Rusya yanlısı tutumları ve Kıbrıs mahalli idarecileri ile İstanbul'daki merkezi hükümet arasındaki yazışmaların uzun sürelerde gerçekleşmesinden rahatsızlık duyulduğu hissedilmektedir. Nitekim İngiliz tarihçi George Hill, Rusya 
konsolosu ile Kıbrıs gümrükleri mültezimi arasına yaşanan gerilimi İngiltere konsolosluk raporlarına istinaden şöyle aktarır:

\begin{abstract}
“Babıâli, Britanya ve Fransa arasında yapılan anlaşma doğrultusunda 1839'da yeni gümrük oranları yürürlüğe konurken, Britanya konsolosu çok geçmeden yeni oranların Britanya ticaretine vurduğu darbeden yakınmaya başladı. Üstelik Diğer ülkeler \%12 oranında gümrük vergisi öderken, Ruslar \%3 ödüyordu. Yani oranların Kıbrıs'ta ticaret yapan, Ruslar hariç, bütün ülkelere zarar verdiğini belirten konsolsos, çeşitli mallar için 1846'da uygulanan gümrük tarifesini veriyor. Örneğin zeytin yağı için \%13,5; orta kalite kırmızı şarap için \%42; Komandarya şarabı için \%72. Öte yandan Rusların hak iddia ettiği imtiyazlı vergi oranlarına itirazlar geliyordu. 400.000 kuruş karşılığında Kıbrıs'ın gümrük gelirleri kendisine iltizama verilmiş olan eski muhassl Sait Mehmet'in Mart 1844'te öğrendiği kadarlyla, Istanbul Emtia Gümrük Emini ondan mültezime talimat vererek Ruslardan \%12 oranında vergi alınmasını istemişti. Böylece Kıbrıs'taki gümrük memuru da bu oranı uygulamaya çalıştı, ama Rus konsolosu ile dragoman ve yeniçeriler zor kullanarak bir nakliyeciye yartm ettiler ve talep edilen oranı ödemeden mallart gemisine yüklemesini sağladılar. Gümrük memuru bu duruma itiraz ederken Mutasarrıf Ethem Paşa meseleyi İstanbul'a havale etti. Tabii İstanbul'dan kara çıkana kadar Rus malları gümrük resmi ödemeden yüklenecekti. Britanya konsolosunun yaptığl gözleme göre, Britanya himayesi altındaki kişiler Rus tüccarlara bir yüzde vererek kendi malların onlar adına yükletiyor ve böylece gümrükten \%9 oraninda tasarruf sağllyordu” (Hill, 1952, s. 179-180).
\end{abstract}

Kıbrıslı Mehmed Bey hakkında dile getirilen şikâyetlerin diğer konsoloslarla herhangi bir ilgisinin olmaması, muhassıl tarafından kendisinin kötü karakterli kişiliği yanında akrabalık ilişkilerinden de bahsedilmesi açık bir yıpratma girişimi gibi gözükmektedir. Rusya konsolosu mültezimden kişisel manada rahatsız olup kendisini şikâyet ettiği ve muhassılı da yanına alarak bir tür baskı kurduğu anlaşılmaktadır. Çünkü iltizam işleri Osmanlı Devletinin egemenliği alanında bir iş olup konsolosun görev alanında değildir.

Rusya konsolosunun Kıbrıs ve bağlı limanların gümrük ihalelerini 1844 y1lı için alan Hacı Mehmed Ağa'dan şikâyetçi olmasının sebebi, Rusya tüccarının Kıbrıs içinde ve Kıbrıs'tan diğer ülkelere yapacakları ticaretin vergilendirilmesiyle ilgisi olabilir. Tahminen, Rusya yaklaşık on yıldır gümrüksüz ihracat yapıyordu. $\mathrm{Bu}$ durum muhassılın da bilgisi dâhilinde idi. Aralarındaki ilişki sebebiyle muhassil Rus konsolosunun usulsüz ticaretine göz yumuyordu. Mehmed Ağa iltizamı aldıktan sonra bu durumu fark etti. Bunun üzerine Rus konsolosunun adamları ile tartışmalar yaşandı. Nitekim Hacı Mehmed Ağa, gümrük ihalesini alınca Rusya Devleti başta olmak üzere, diğer ecnebi tüccar ve tebaası hakkında nasıl bir vergilendirme yapacağını İstanbul'a sordu (KȘS., 39/160-2). Bunun üzerine kendisine verilen cevapta, Rusya tüccarının yerli mahsulü ülke içinde yahut ülke dışına satması halinde toplamda \%12 gümrük vergisi ödemeleri gerektiği bildirilmişti. Öte yandan dışarıdan Osmanlı ülkesine getirecekleri emtia ve eşyadan da \%5 gümrük vergisi alınacağı bildiriliyordu (KŞS., 39/160-2).

$\mathrm{Bu}$ çerçevede, "Kıbrls ve tevâbi 'i cezîreleri gümrükleri işbu altmış senesine mahsûben ber-vech-i maktû' Hacı Mehmed Ăga'nın uhdesine ihâle olunmuş olduğundan gümrük rüsûmâtının istihsâli emrinde Rusya Devleti ile sâ'ir düvel-i ecnebiye tüccâr ve teb 'ası haklartnda ne vechile mu'âmele olunması ağa-yı mûmâ-ileyh tarafindan bâ-arzuhâl inhâ ve istîzân olunmuş olduğundan keyfiyyet Gümrük emîni sa 'âdetlü beyefendi hazretlerinden lede'l-isti lâm dâhil-i mu'âhede-i cedîde-i ticâret olan düvel-i mütehâbbe tüccâr ve teb 'asının Memâlik-i Mahrûse-i Şâhâne mahsûlünden olup yine derûn-ı Memâlik-i Mahrûse'de bey ' u fürûht ve yâhûd diyâr-ı âhare nakl edecekleri bi'lcümle emti 'a ve eşyâ ve erzâkın îcâb eden yüzde dokuz âmediye ve üç reftiye ki cem 'an yüzde on iki guruş rüsûmât-l gümrügünü te'diye ve îfâ ve diyâr-ı ecnebiye mahsûlü olarak Memâlik-i Mahrûse-i Şâhâne'ye getürdükleri emti'a ve eşyântn yüzde üç âmediye ve rüsûmât-ı sâ'ireye mukâbil olan yüzde iki daha resm-i munzamı ki cem 'an yüzde beş guruş resm-i gümrügünü̈ hîn-i 
vürûdunda tamâmen te'diye ve teslîm eylemeleri mukarrer olduğundan Rusya Devleti tüccâr ve teb 'ası haklarında dahi ol vechile mu âmele olunması [...]” (KŞS., 39/160-2) istenmişti.

Ancak, İstanbul'dan üç ay kadar sonra Kıbrıs makamlarına gönderilen diğer bir emir, bahsedilen gümrük vergisi oranlarının yanlışlıkla yazıldığını, söz konusu yazının "Bir güne hükmü kalmadığı" bildiriliyordu (KȘS., 39/163-2, ). Yani Rusya tüccarları Kıbrıs’ta eski vergi nizamına göre ticaret yapacaklard.

\section{Sonuç}

XVIII. yüzyılın son çeyreğinden itibaren anlaşmalar üzerinden temin ettiği haklarla Osmanlı ülkesinde ticaret yapma hakkı elde eden Rusya, Kıbrıs'ta da konsolosluk kurarak faaliyetlerini başlattı.

Osmanlı Devleti ve Rusya arasındaki ilişkilerin tarihi seyri, Rusya konsoloslarının ve tüccarlarının adadaki faaliyet grafiğinde zamana bağlı değişkenliklere yol açtı. Savaş yıllarında ilişkiler bozulurken barış dönemlerinde Rus tüccarları adadan çeşitli mallar aldılar. Rus konsoloslar da devletlerinin Osmanlı politikası çerçevesinde zaman zaman iç işlerine müdahale ettiler.

1838 yılında Osmanlı Devleti'nin İngiltere ile yaptığı Balta Limanı Ticaret Antlaşması, görünürde İngiltere tüccarları lehine bir ticaret ve vergilendirme rejimi yaratmıştı. Ancak İngiltere bu rejimden Rusya Devleti aleyhinde olarak rahatsızdı (Kütükoğlu, 2013, s. 202 vd). Çünkü anlaşmanın öngördüğü ihracat gümrükleri Rusya tüccarları için geçerli değildi. Haliyle Rusya tüccarlarının, Osmanlı ülkesinden temin edip ihraç ettikleri malların gümrük vergilerinin bir kısmını ihraç ettikleri ülkenin tüccarı, bir kısmını da Rusya tüccarlarına mal satan Osmanlı yerel üreticileri ödemekteydi.

Kıbrıs'taki gümrük mukataalarını iltizama alan mültezimler ile adadaki Rusya konsolosunun arasında yaşanan vergilendirme çekişmesinin sebebi, bir bakıma bireysel olarak mültezimin gelir kaynağındaki azalma olarak su yüzüne çıkmış; konsolos tarafındanise tüccarlarından fazladan vergi tahsilatı yapılmak istendiği şekliyle anlaşılarak, İstanbul hükümeti nezdinde şikâyetçi olmuştu. $\mathrm{Bu}$ şekilde konsolos ve mültezim arasında gerçekleşen vergi hususunun, daha geniş kapsamlı bir politikanın uzantısı olduğu anlaşılmaktadır.

Osmanlı Devleti, 1838 Balta Limanı Ticaret Antlaşması ile İngiltere’ye en fazla imtiyaza sahip devlet statüsü vermişti. İngiltere bu durumda diğer Avrupa devletlerine nazaran büyük bir avantaj elde etmişti. Muhtemeldir ki bu durumu Osmanlı Hükümeti farkında olarak idare ediyordu. Mısır Meselesi hengâmında İngiltere'nin sağladığı destek bir manada bu şekilde ödeniyordu. İşte tam da bu süreçte Osmanlı Hükümeti, İngiltere'nin tek başına Osmanlı ekonomisi üzerinde açmakta olduğu derin tahribatı önlemek istemişti. Bunun için de Rusya faktörü bir denge unsuru olarak düşünülmüş olmalıydı. Rusya tüccarlarının bu şekildeki bir gümrük tarifesiyle ticaret yapmalarına müsaade edilerek, Osmanlı ülkesinin tek başına İngiltere hâkimiyetine geçmesini önleyici bir denge siyaseti yürütülmeye çalışılmıştı. O sebeple de ada idarecilerine konuyla ilgili yazılan emirde, bu statünün, sehven yazılan bir maddeye dayandırıldığı belirtilmiş olmalıydı. Nihayet yabancı ve büyük bir iktisadi güç olan İngiltere'ye karşı yabancı ve büyük bir güç olan Rusya arasında temin edilmeye çalışılan dengenin en büyük handikabı, her ikisinin de Osmanlı ticaretini ve ekonomisini bunlara açmaktan ibaret olmasıydı. Devlet, üretici bir ekonomi inşa etmemişti. 


\section{Kaynaklar}

\section{A. Arşiv Kaynakları}

\section{K.K.T.C. Millî Arșiv ve Araștırma Dairesi}

a)Kıbrıs Şer'iyye Sicilleri (KŞS.):KȘS.,18/125-1; KŞS., 21/29-3; KȘS., 24/32-2; KȘS., 26/14-2; KŞS., 26/24-1; KŞS., 26, 24-2; KȘS., 27/23-1; KŞS., 27/99-1; KŞS., 27/126-3; KȘS., 27/179-1; KŞS., 27/161-1; KŞS., 28/107-2; KȘS., 29/97-1; KȘS., 30/18-1; KȘS., 30/121-3;KȘS., 30/140-3; KȘS., 30/140-4; KȘS., 30/178-2; KȘS., 31/112-1;KȘS., 33/52-1; KȘS., 33/87-1; KȘS., 33/174-1; KȘS., 35/106-1; KȘS., 35/115-2; KȘS., 35/116-1; KȘS., 35/127-2; KȘS., 35/143-1; KȘS., 35/167-1; KȘS., 36/47-2; KŞS., 36/106-2; KŞS., 36/143-1;KŞS., 38/128-1; KŞS.,KŞS., 39/17-1; KŞS., 39/160-2; KŞS., 39/163-2; KȘS., 40/30-1;KȘS., 40/156-1;KȘS., 41/77-1; KȘS., 41/100-1; KȘS., 41/77-1; KȘS., 41/100-1; KŞS., 42/140-1.

\section{T.C. Cumhurbaşkanlığı Osmanlı Arşivi Kaynakları}

a) Temettuat Defterleri

1) Cumhurbaşkanlığı Osmanlı Arşivi (BOA.)Maliye Varidat Muhasebesi Temettuat Defterleri (ML.VRD.TMT.d.): 16153.

b) Vesikalar

1) Cumhurbaşkanlığ 1 Osmanlı Arşivi (BOA.) Sadaret Mektubi Kalemi Evrakı (A.MKT.) (Dosya No/Gömlek No): 14/67.

2) Cumhurbaşkanlığı Osmanlı Arşivi (BOA). Sadaret Mektubî Kalemi Belgeleri, Hâriciye Mektubî Kalemi Evrakı (HR.MKT.) (Dosya No/Gömlek No):37/80.

3. Salnameler

Salnâme-i Vilâyet-i Cezâyir-i Bahr-i Sefid, Def’a. 1, sene 1287.

B) Araştırma ve İncelemeler

Aksın, A. (2002). Osmanl1-Rusya Ticari Münasebetleri (1787-1830).XIV. Türk Tarih Kongresi, Ankara:9-13 Eylül 200, Kongreye Sunulan Bildiriler. 2(2), 1027-1042.

Anderson, M.S. (1954). Great Britain and the Russo-Tuskish War of 1768-1774. The English

Historical Review. Oxford: Oxford University Press,69(270), 3958.(http://www.jstor.org/stable/556292).

Ayar, M. (2012). XIX. Yüzyılın İkinci Yarısında Tuzla (Larnaka): Ticaret Mahkemesi ve Konsolosluklar. History of Ottoman Larnaca. E. Balta, T. Stavrides, I. Theocharides (Ed.). İstanbul: Isis, 347-380.

Bağış, A.İ. (1983).Osmanlı Ticaretinde Gayri Müslimler ve Kapitülasyonlar-Beratlı Tüccarlar, Avrupa ve Hayriye Tüccarları (1750-1839). Ankara: Turhan.

Beydilli, K. (1998). Hünkâr İskelesi Antlaşması. Türkiye Diyanet Vakfi İslam Ansiklopedisi (Cilt 18). İstanbul: Türkiye Diyanet Vakf1, 488-490.

Çapraz, H. (2012).Rusya Dış Ticaret Politikasında Güney Kafkasya (19. Yüzyıl). Isparta: Fakülte.

Çevikel, N.(2000). Kıbrıs Eyaleti: Yönetim, Kilise, Ayan ve Halk (1750-1800).Gazimağusa: Doğu Akdeniz Üniversitesi.

Çoruh, H. (2008).II. Mahmud Döneminde Kıbrıs'ın İdarî, İktisadî Ve İctimaî Yapısı (18081839).İstanbul: Marmara Üniversitesi Türkiyat Araştırmaları Enstitüsü, Türk Tarihi Anabilim Dalı Yakınçağ Tarihi Bilim Dalı, Yayımlanmamış Doktora Tezi.

Delaval, C.C. (1908).Excerpta Cypria: Materials For A History Of Cyprus. Cambridge: Cambridge University Press.

Demiryürek, M., (1826). Düzenlemesinden Sonra Kıbrıs İhtisâb Rüsûmu (1828-1838).Belleten, 76, (276),553-605. 
Demiryürek, Mehmet, (2015). The Consulate Of Russia İn Cyprus İn The Later 18th And Early 19th Century. XVI. Türk Tarih Kongresi (20-24 Eylül 2010, Ankara), Kongreye Sunulan Bildiriler: Osmanlı Tarihi.(Cilt. 4, Kısım: 2). Ankara: TTK,715-726.

Dinç, G. (2010). Osmanlı Yönetiminde Kıbrıs (1800-1839). Antalya: Akdeniz Üniversitesi Sosyal Bilimler Enstitüsü, Tarih Anabilim Dalı, Yayımlanmamış Doktora Tezi.

Dinç, G. (2018). The Effects Of The Ottoman-Russian War Of 1768-1774 İn The Mediterranean: The Case Of Cyprus İn The Light Of Ottoman Documents. Journal Of Mediterranean Studies: History, Culture, and Society İn The Mediterranean World. Malta: The University Of Malta, 27(1), 63-76.

Erdönmez, C. (2013). Tanzimat Devrinde Bazı Kıbrıs Rumlarının Yunan Vatandaşlığına Geçmelerinden Kaynaklanan Hukukî Meseleler. Bilig, 64, 175-197.

Gazioğlu, A.C. (2000).Kıbrıs'ta Türkler 1570-1878., Lefkoşa:Kıbrıs Araştırma ve Yayın Merkez (CYREP).

Hill, S.G. (1952).A History of Cyprus. Vol. IV, Cambridge: Cambridge University Press.

Hill, S.G.Kıbrıs Tarihi (2016): Osmanlı ve İngiliz İdaresi Dönemi 1571-1948.Serbest, N:C. (Çev.). İstanbul: Türkiye İş Bankası.

Jorga, N. (2005).Osmanlı İmparatorluğu Tarihi, C.V, (Çev. Epçeli, N.).İstanbul: Yeditepe.

Kütükoğlu, M.S. (2013). Balta Limanı'na Giden Yol: Osmanlı İngiliz İktisâdî Münâsebetleri (1580-1850).Ankara: TTK.

Kütükoğlu, M.S. (2018). Osmanlı'nın Sosyo-Kültürel ve İktisâdî Yapısı. Ankara: TTK.

Köse, O. (2006a).1774 Küçük Kaynarca Andlaşması (Oluşumu-Tahlili-Tatbiki). Ankara: TTK.

Köse, O. (2006b). Balkanlarda Rus Konsolosluklarının Kuruluşu ve Faaliyetleri.Turkish Studies/Türkoloji Araştırmaları, 2, 141-155. (http://www.turkishstudies.net/sayilar/sayi2/kose.pdf).

Kurtaran, U. (2014). Sultan Birinci Mahmud'un Rusya'ya Verdiği 1739 Tarihli Ahidnâmenin Diplomatik Açıdan Tahlili. Tarih İncelemeleri Dergisi, 29(1),213-232.

Kurat, A.N. (1990). Türkiye ve Rusya. Ankara: Kültür Bakanlığı.

Luke, S.C.H. (1969)Cyprus under the Turks 1571-1878:A Record Based On The Archives Of The English Consulate İn Cyprus Under The Levant Company And After. London: C. Hurst \& Company.

Ortaylı, İ. (2001).İmparatorluğun En Uzun Yüzy1lı. İstanbul: İletişim.

Özkul, A.E. (2013). The Consuls And Their Activities İn Cyprus Under The Ottoman Administration (1571-1878).Turkish Studies-International Periodical For the Languages, Literature, and History Of Turkish Or Turcic, Vol: 8(2),239-283.

Prousis, T.C. (2003). Russian Trade Prospects İn Smyrna: An 1812 Consular Report. History Faculty Publications. 8, 127-138. (http://digitalcommons.unf.edu/ahis_facpub/8).

Saul, N.E. (1970). Russia and the Mediterranean (1797-1807). Chicago and London: The University of Chicago Press. 